\title{
3D SIMULATION AND GEOMORPHIC PREDICTION FOR FLOOD RISK IN MONSOON REGION OF PENINSULAR MALAYSIA
}

\author{
Ibrahim Sufiyan ${ }^{1 *}$, J.I Magaji ${ }^{2}$ \\ Department of Geography, Nasarawa State University Keffi, Nigeria \\ *Corresponding Author Email: ibrahimsufiyan0@gmail.com
}

This is an open access article distributed under the Creative Commons Attribution License, which permits unrestricted use, distribution, and reproduction in any medium, provided the original work is properly cited.

\section{ARTICLE DETAILS}

\section{Article History:}

Received 4 January 2019 Accepted 7 February 2019 Available online 12 February 2019

\begin{abstract}
Everyday it rains heavily during the monsoon period around December to January in Terengganu watershed especially near to the South China Sea is experiencing a flash flood. the flood is usually occurring in most of the states in Peninsular Malaysia. the use of Geographic information system to identify those zones which are vulnerable to flood risk was employed. The method is to characterize different hydrologic response units into subbasins which were adopted using the Soil Water Assesment Tool (SWAT). The geomorphic factors of soil, land use and slope have greatly influenced the water flow that causes the flood. the Terengganu watershed was delineated and the flood risk at individual subbasin parameter was simulated in form of real-time simulation. All the scenario within the catchment was calculated for easy mitigation. The flood risk models were developed for the purpose of planning and management. the HRUs are found to be vulnerable to flood risk with a greater impact of soil and land cover in the Terengganu River catchment area.
\end{abstract}

KEYWORDS

GIS, HRUs, Delineation, Watershed, Flood Risk

\section{INTRODUCTION}

Flood is one of the naturally occurring phenomena that affect Malaysia. The hazard and the risk go beyond a reasonable doubt. The Malaysian government spent a hefty sum to control and manage flood disaster. Between 1926 to 2001 around RM 915 million was estimated to be spent in Malaysia [1]. The attempt to employ modern techniques of software to determine better flood warning system, decision making as well as mitigation are however incorporated based on hydrological model and Geographic Information System which was considered as the new technology of solving flood problems [2].

The recent technology of remote sensing and geographic information system (GIS) has capabilities of locating, mitigating managing and analyzing areas vulnerable to flood hazard event [3]. This study involved the application of soil water assessment tool (SWAT) to determine the fundamental hydrologic response units (HRUs) as well as to develop watershed delineation within the catchment area of Kuala Terengganu. The flood mitigation measures require analytic management of the watershed as affluent to engineering approaches in controlling flood risk and hazard in the environment. The use of 3D to develop flood simulation is paramount especially for quite flood alert warning and emergency relief to flood victims. The study area that is Kuala Terengganu has been experiencing flash flood particularly during the monsoon period of strong rain-bearing wind. The effort was made to address the issues of flood impact base on the digital image processing and high multispectral resolution of satellite imagery.

According to a researcher, GIS is recognized as a powerful tool in regulating and analyzing data from different sources and flood risk mapping was presented at various platforms of urban growths simulating and consequences of alternative cases [4]. Another researcher also relate importance to introduced input parameters that necessitate uses of spatial analysis to the real world and enhance decision making [5]. A researcher discusses the relevance of GIS-based methodology for rainfall-runoff modeling which has been developed. While another author included several parameters in their rainfall-runoff model such as (land use, soil types, and DEM) [6]. Rainfall was to estimate spatial distinction between average flow and runoff in the river basin. A group of researchers described simulation stream flow impact with SWAT in response to historical land use [7].

According to a researcher that reported that the resolution of the Digital Elevation Model (DEM) had played an essential role in watershed delineation and SWAT simulation [8]. The use of climate data was stressed by a previous scholar [9]. SWAT was also tested by another scholar to document 30 years (1962-1991), long-term average soil moisture condition and variability, and topsoil variability in Oklahoma [10]. Several studies previously showed and indicated promising result using SWAT as a hydrologic model [11-15]. SWAT was used to simulate soil moisture in the large River basin in Taxes by a researcher [16]. SWAT was also used by another researcher [17].

However, there is a limited study of combining SWAT and 3D to obtain flood risk simulation in the watershed. Most of the researches conducted by SWAT discuss more of sediment yield and deposits, soil erosion, nutrients loss, stream flow, rainfall intensity and groundwater movement.

\subsection{Objectives}

The research will focus on the followings;

1. Developing Hydrologic Response Units within the Geomatic subbasin

2. $\quad$ Create a 3D environment for flood visualization

3. To run the simulation the flood risk zone for prediction 


\section{MATERIALS AND METHODS}

\subsection{Study Area}

The Terengganu catchment has a total area of the Terengganu River catchment area is 286,507 [ha] or 707,973 [acres]. There are about 25 sub- basin parameters and 305 Hydrologic Response Units (HRUs) the catchment lies within the wet tropical equatorial climate that exhibits vital roles in manipulating weather that generate monsoon from the NorthEast, soil, organic matter and sediment yield are all drained into the South China Sea. It is located at upper left corner $50^{\circ} 30 / .40 / / \mathrm{N}, 102^{\circ} 23 / 15 / / \mathrm{E}$ and the lower right corner is $40^{\circ} 39 / 25 / / \mathrm{N}, 103^{0} 11 / 62 / / \mathrm{E}$ [18].

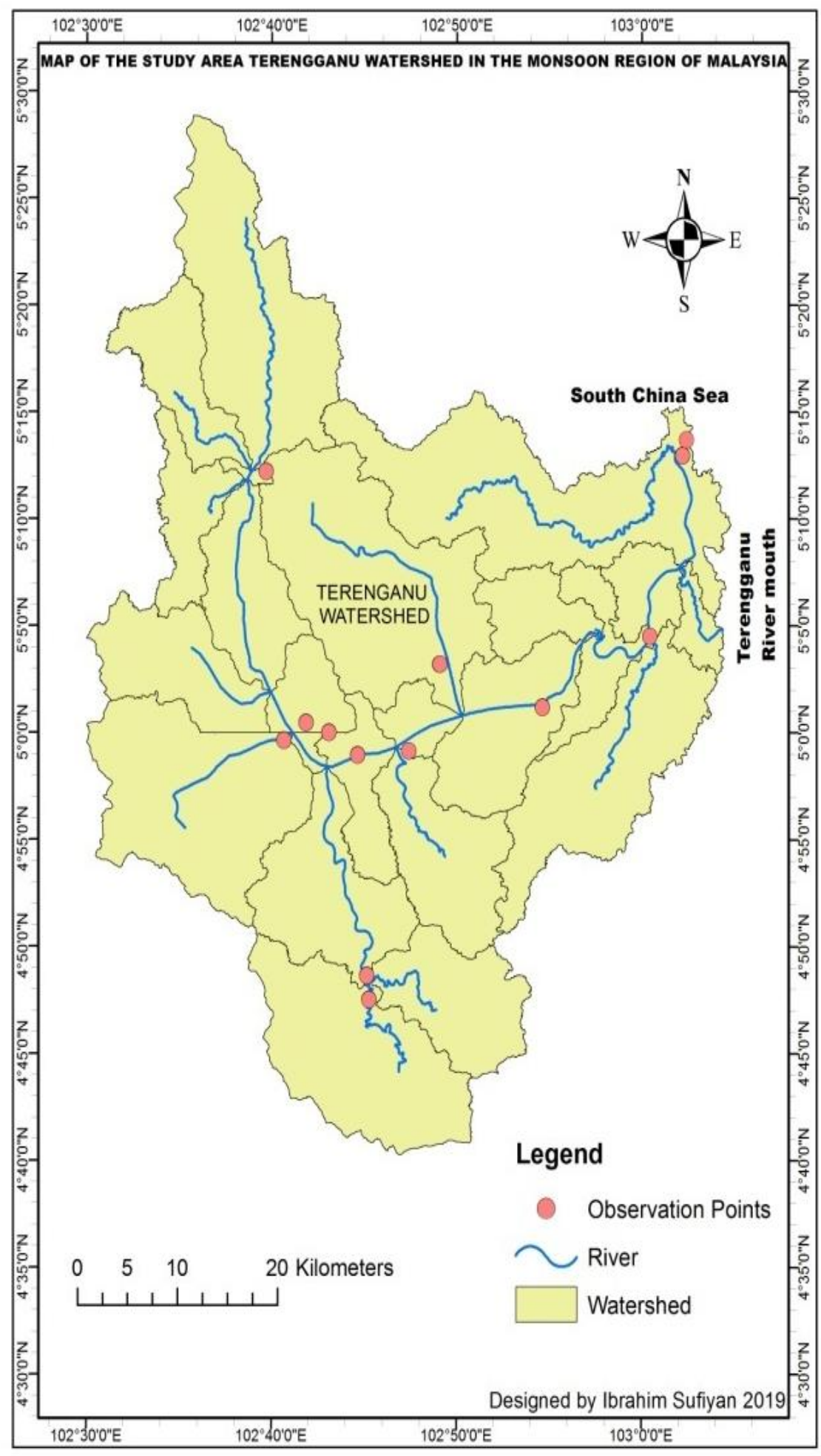

Figure 1: Study Area, Terengganu River Catchment

The flood mapping generally considered the geographical references for the much-needed data as it occurs in different formats. For the purpose of this study, emphasis is given on the required and optional data input from both Geographic Information System (GIS) and Remote Sensing. The ground survey was conducted in other to obtain recent and up-to-date information about the land cover pattern, soil types and the slope classes.
The output data must have been expected to produce predictable results for simulation in ArcScene. The 3D simulation is conducted in order to visualize the flood event in Terengganu River catchment. Nerus River is the most significant tributary following Strahler's order number 6 with drainage density of 2.64 [19]. 


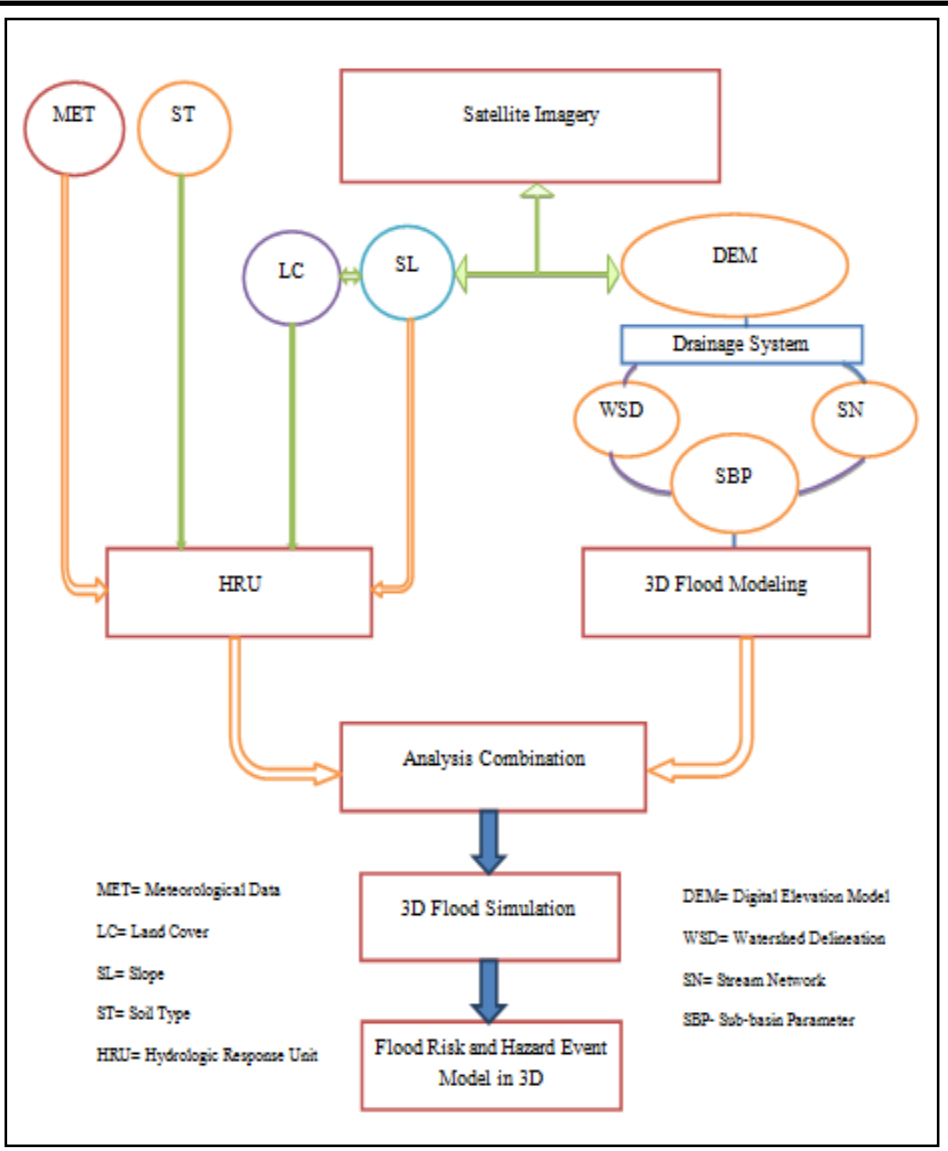

Figure 2: Flow Chart of the study

\subsection{SWAT Data Sources}

1. Department of Irrigation and Drainage (DID)

a. Data for a flood event in the study area (previously)

b. Stream flows data, these are obtainable base on a different location of the stations

2. Climate data from Malaysian Meteorological Department (MET Malaysia) from 2000-2015

3. Land cover images from the Malaysian Remote Sensing Agency (MRSA)
4. Malaysian soil map was obtainable from online source European Digital Archives of soil maps (EuDASM) named Reconnaissance soil map Peninsular Malaysia 1968.

The parameter needs a background of accurately imputed data (database) of Digital Elevation Model (DEM). Soil types, land cover and subdivide the basin into sub-basins based on the direction of it flow which is acquired from the DEM. The system extracts each input data from the database created, after that, it will directly delineate the watershed and categorized them into hydrologic response units (HRUs) which have unique combinations of land cover and soil types and slope for each sub-basin [20].

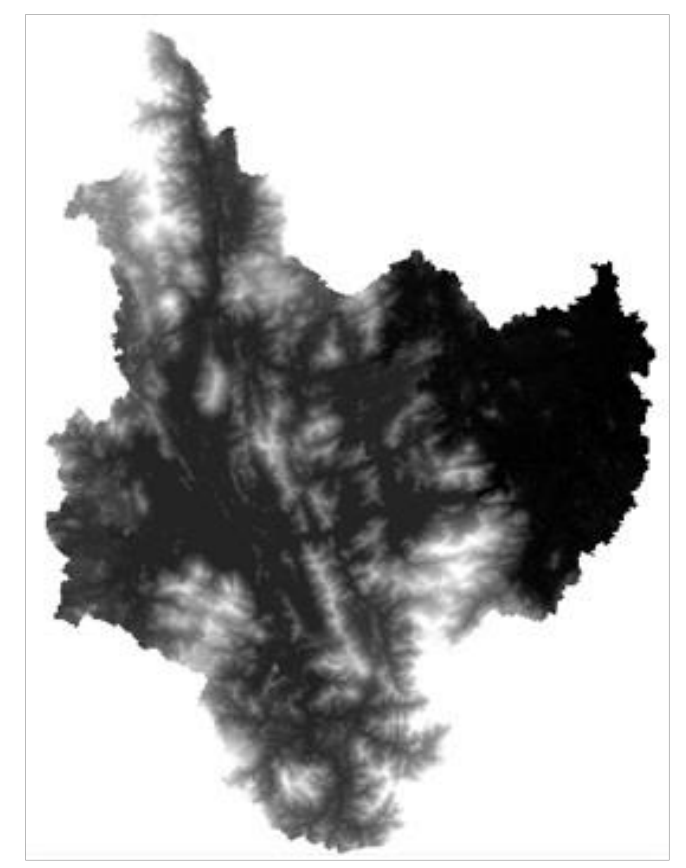

Figure 3: Digital Elevation Model (DEM) 30M Resolutions of Terengganu River Catchment Area 
The figure below is the SWAT Interface use for watershed delineation. According to a researcher, SWAT models is a long-time and a continuous model designed for simulation of watershed it operates on a daily time and step by step to predict the significant impact on water, sediment agriculture, nutrient- chemical yield and their management in the streams [21].

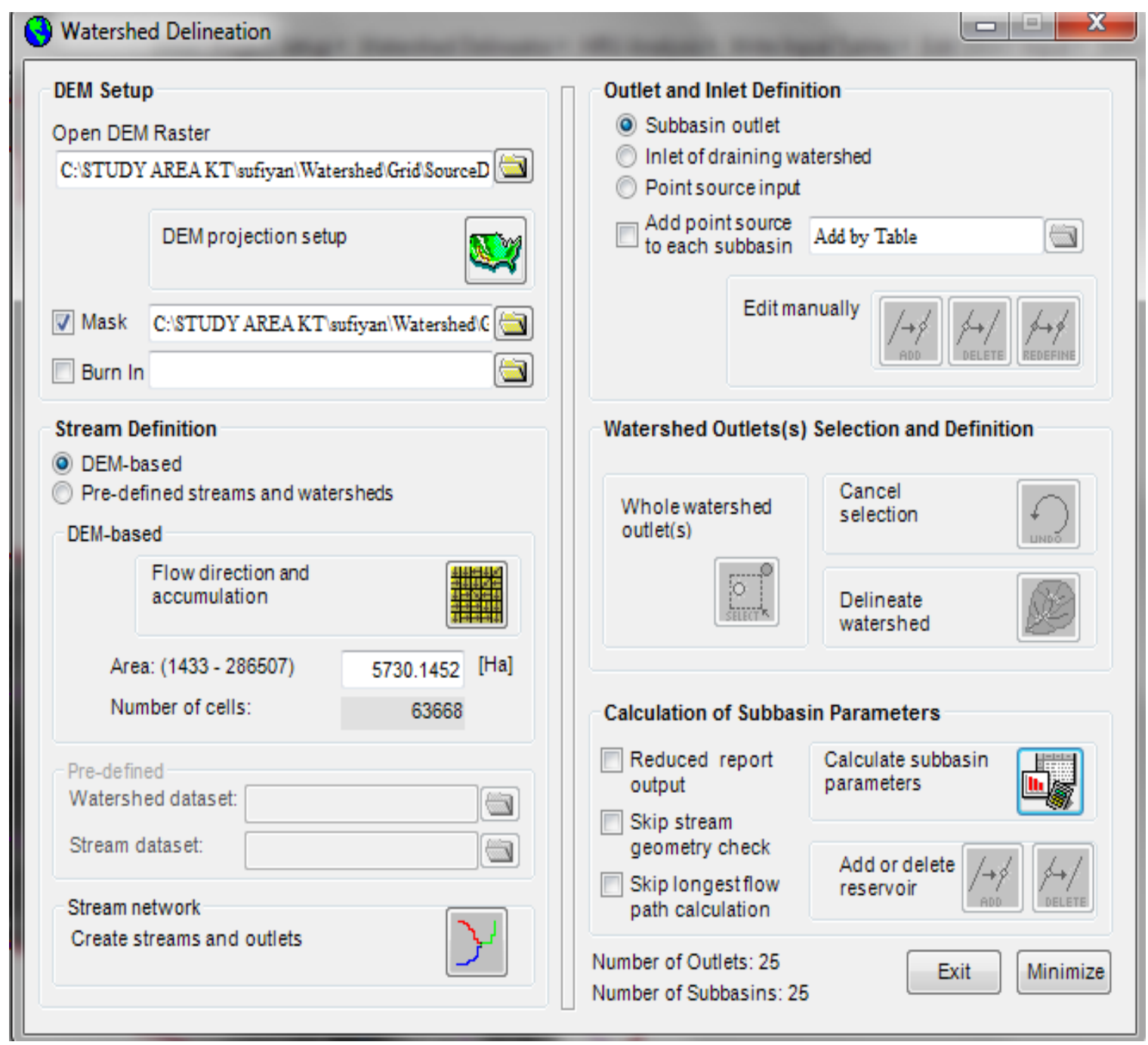

Figure 4: SWAT Interface Analysis

\section{RESULT AND DISCUSSION}

The result obtained shows that the Terengganu River catchment has the total area of 286,507 hectares equivalent to 707,973 acres, with existing 25 sub-basins parameter and 305 Hydrologic Response Units (HRUs). Refer to table 1 below

Table 1: Total area of the watershed

\begin{tabular}{|c|c|c|l|}
\hline $\begin{array}{c}\text { Watershed } \\
\text { Number of } \\
\text { Sub-basins }\end{array}$ & Area [ha] & Area[acres] & $\begin{array}{l}\text { Number of } \\
\text { HRUs }\end{array}$ \\
\hline 25 & 286,507 & 707,973 & 305 \\
\hline
\end{tabular}

Watershed is also known as a basin or catchment, or merely an area delineated with a specified outlet point that emptied in a large body of water. The figure below represents the delineated watershed of Terengganu River Catchment Area. Figure 5 below is the result obtained from the SWAT watershed delineation 


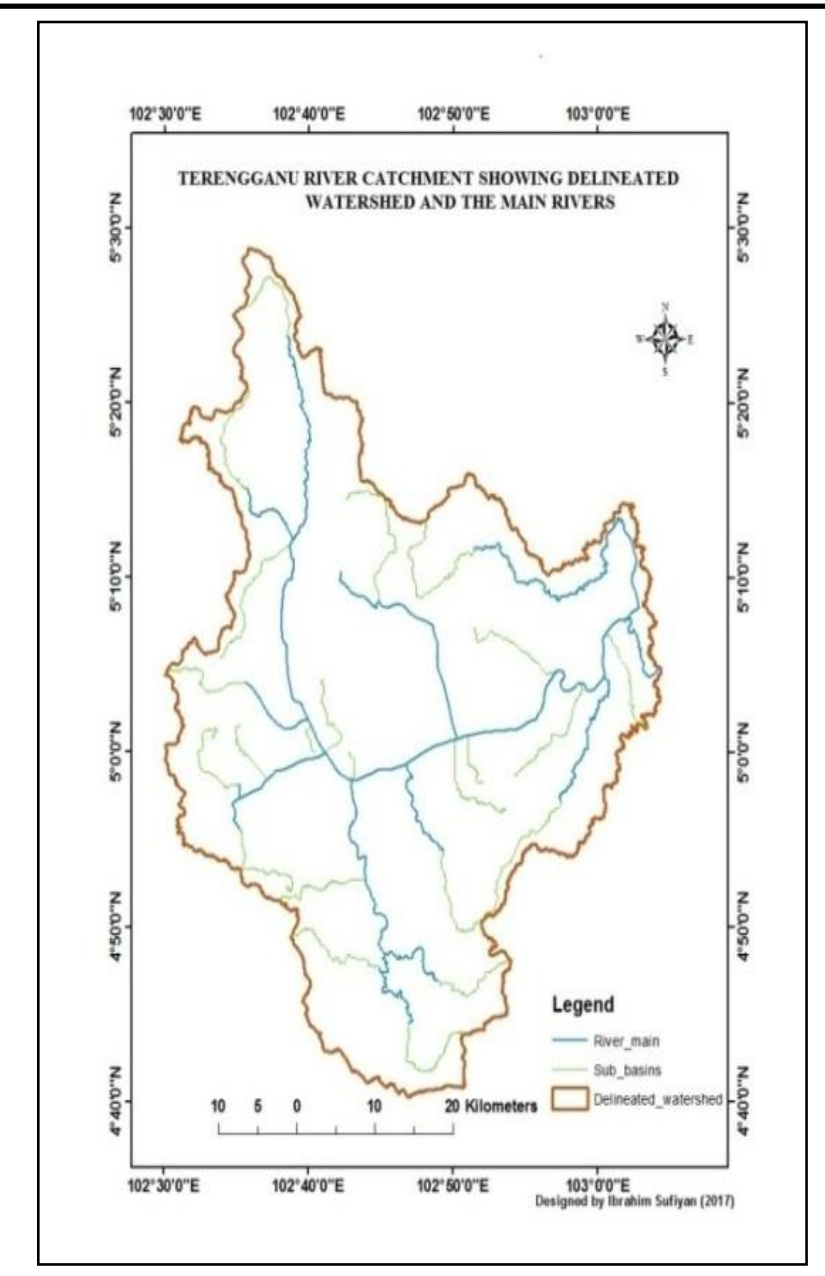

Figure 5: Delineated watershed of Terengganu

The stream links are developed through the stream network. 10 stream links are obtained from the Terengganu river catchment area. Each stream link had been connected with the defined sub-basin which contributes a certain amount of water that flows due to the gradient of the slope. Figure
6 illustrates the main streams and the reservoirs found in the Terengganu watershed.

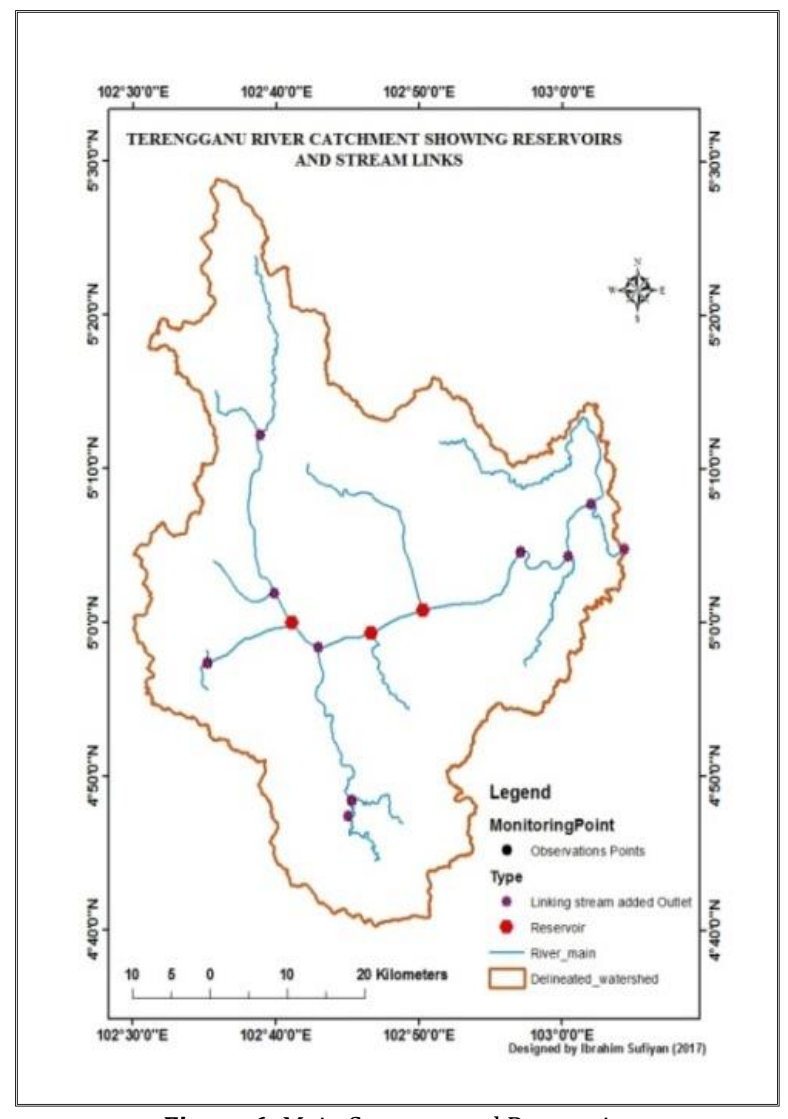

Figure 6: Main Streams, and Reservoirs

The 25 different sub-basins are having distinct parameters from one another as shown in figure 7. Depending on the characteristics of the individual sub-basin; each might have different HRUs reports at a different scenario.

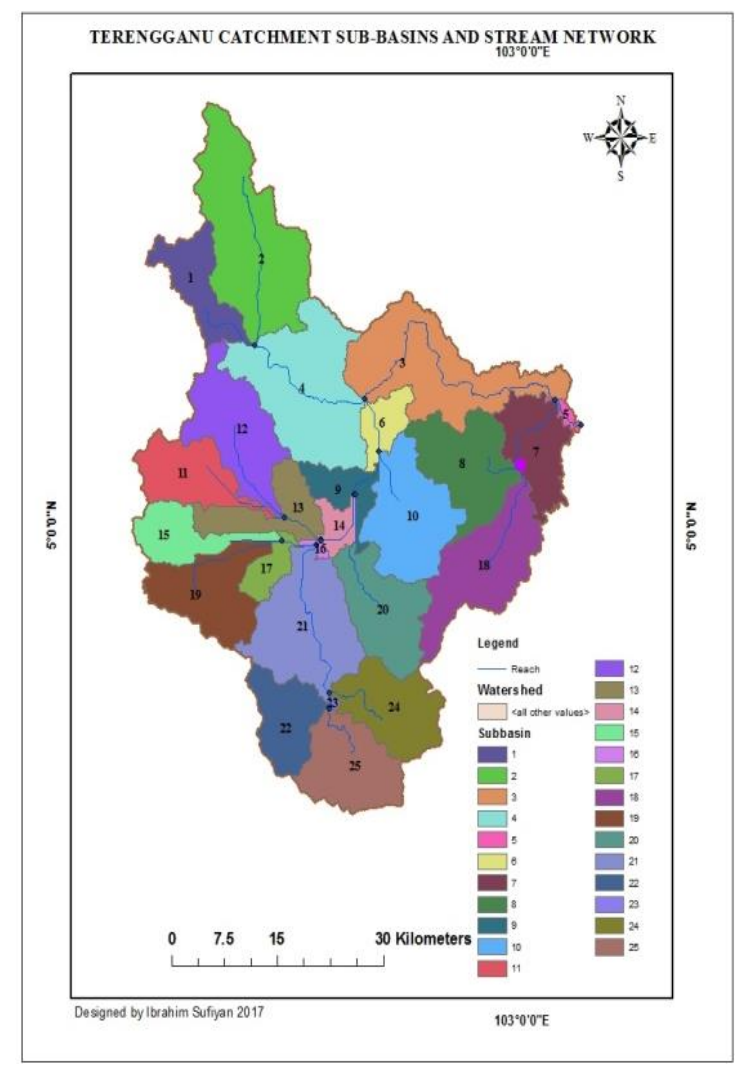

Figure 7: Sub-basins Parameters of Terengganu River Catchment 
The Terengganu River catchment has a unique pattern of sub-basins. Figure 7 clearly distinguishes the 25 sub-basins parameter in a different model. In the same figure, the rivers were superimposed to the numbers of sub-basins. The overlaid streams network enters into the entire individual stream within the catchment. in sub-basins that are vulnerable to flood risk in the Terengganu River catchment area. The analysis done in Geographic Information System had suitably labeled the affected HRUs and the summary of the flood risk impacts are displayed in table 2 . While, figure $9,10,11,12$ and 13 is showing the HRUs location in the cropped sub-basin 3, 5, 7, 8 and 18.

The map in figure 8 is the presentation of Hydrologic Response Units HRUs

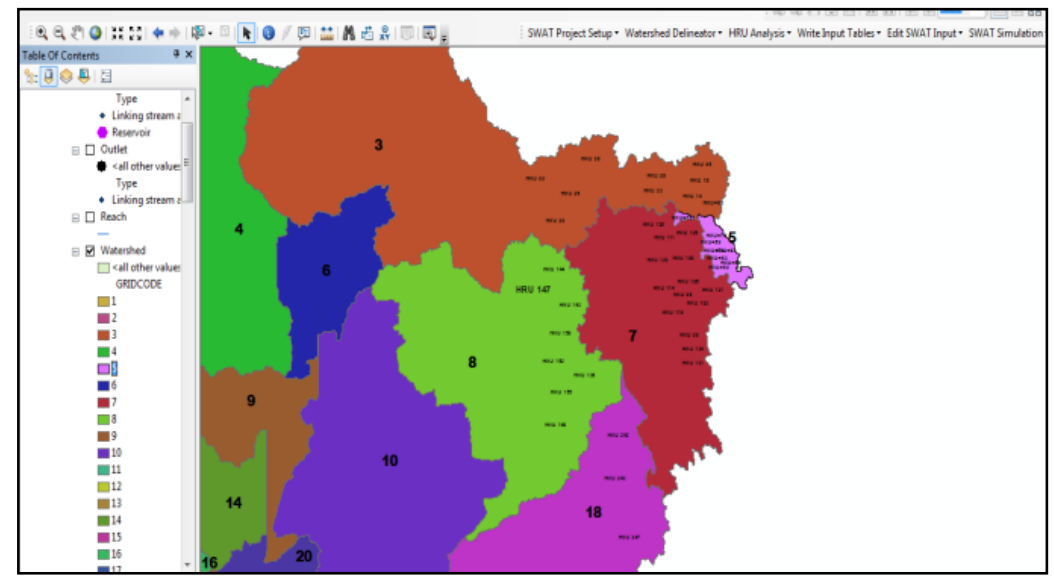

Figure 8: above is the illustration of the position of HRUs found in 5 sub-basins in Terengganu River catchment area

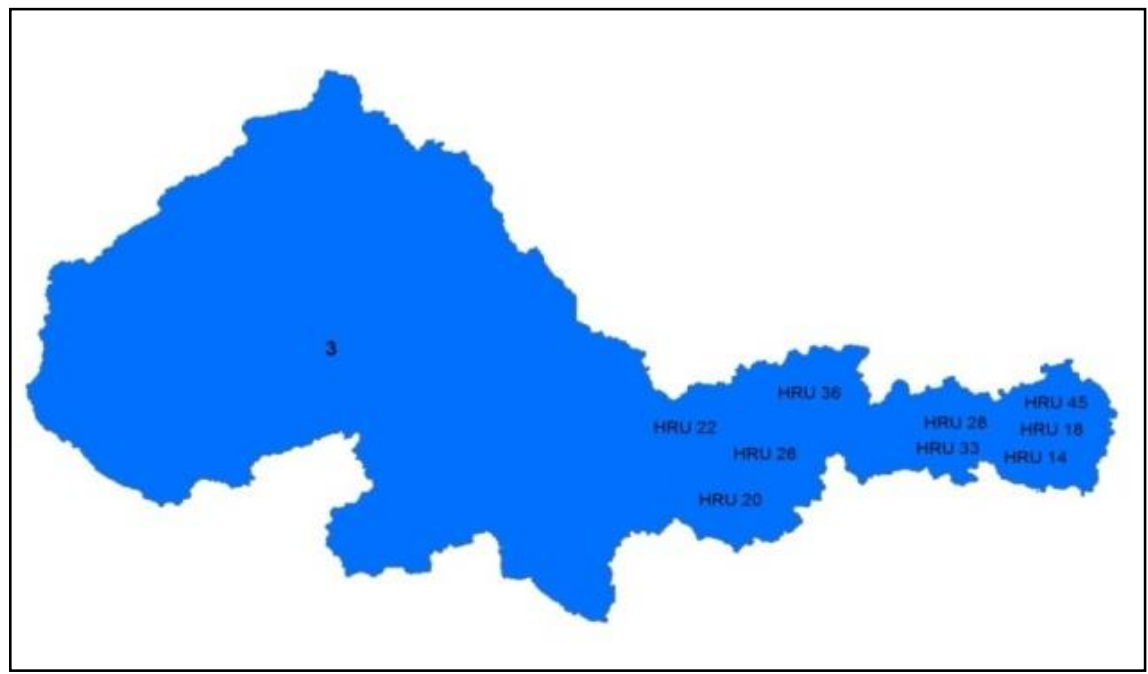

Figure 9: shows the cropped sub-basin and HRUs found in sub-basin 3 of Terengganu River catchment area

The figure 10 below is the cropped illustration of the position of HRUs found in sub-basin 5 in TerengganuRiver catchment area.

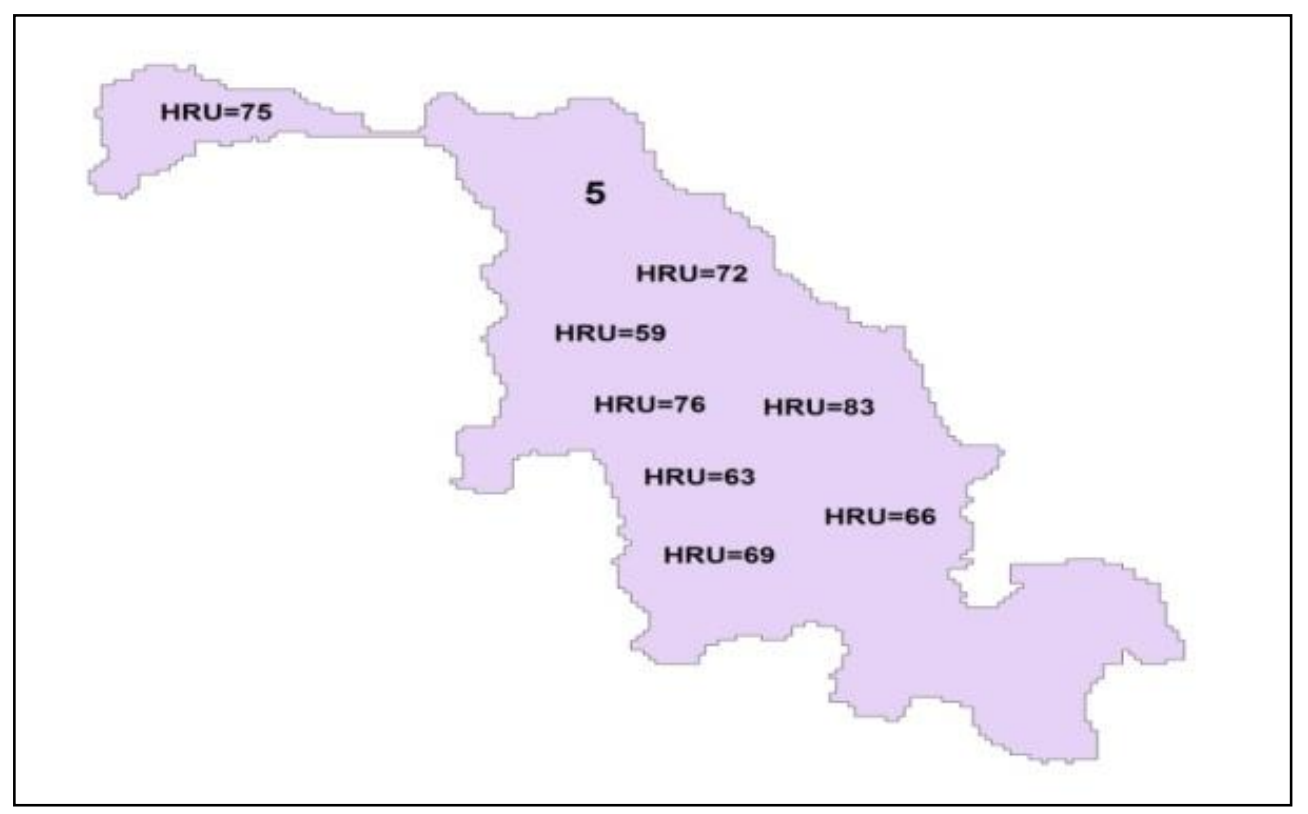

Figure 10: Showing the HRUs found in sub-basin 5 of Terengganu River catchment area 
The figure 11 below is the cropped illustration of the position of HRUs found in sub-basin 7 in Terengganu River catchment area.

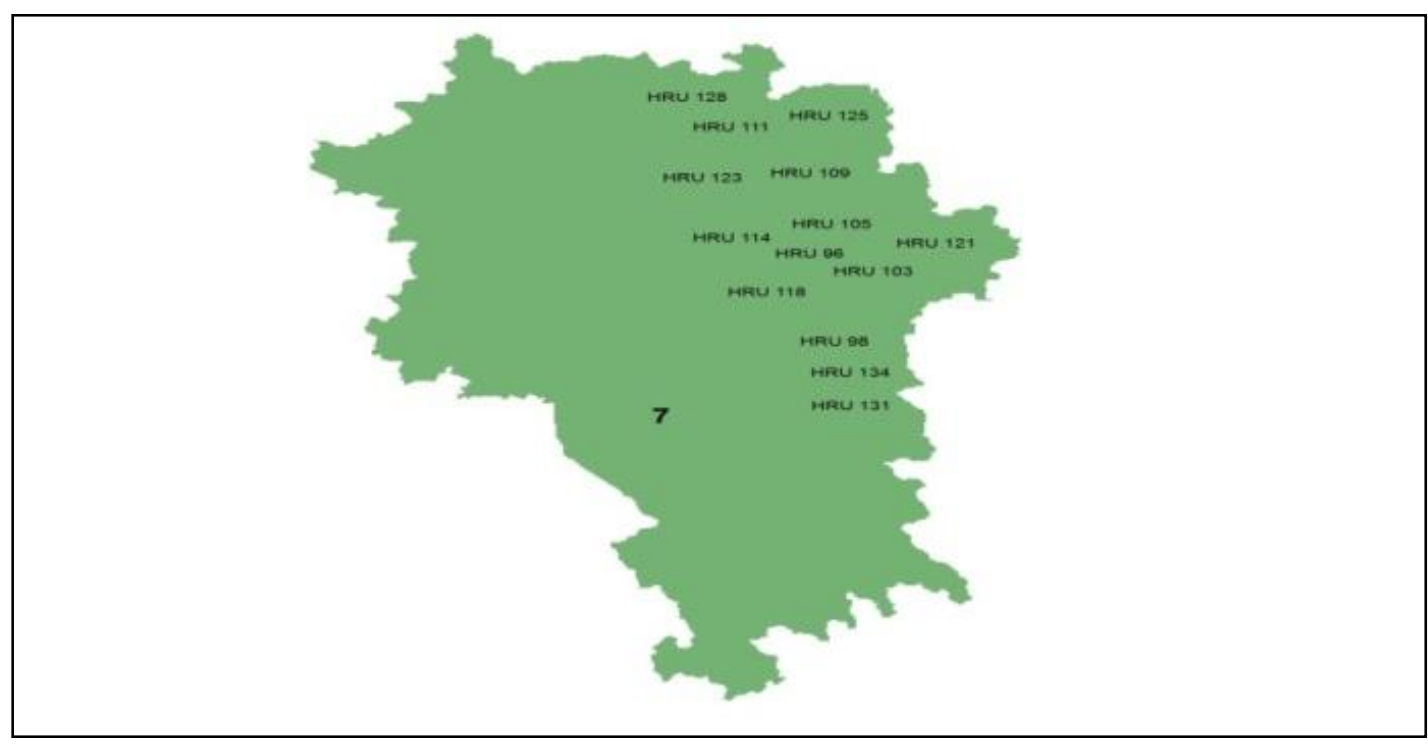

Figure 11: Showing the HRUs found in sub-basin 7 of Terengganu River catchment area

The figure 12 below is the cropped illustration of the position of HRUs found in sub-basin 8 in Terengganu River catchment area.

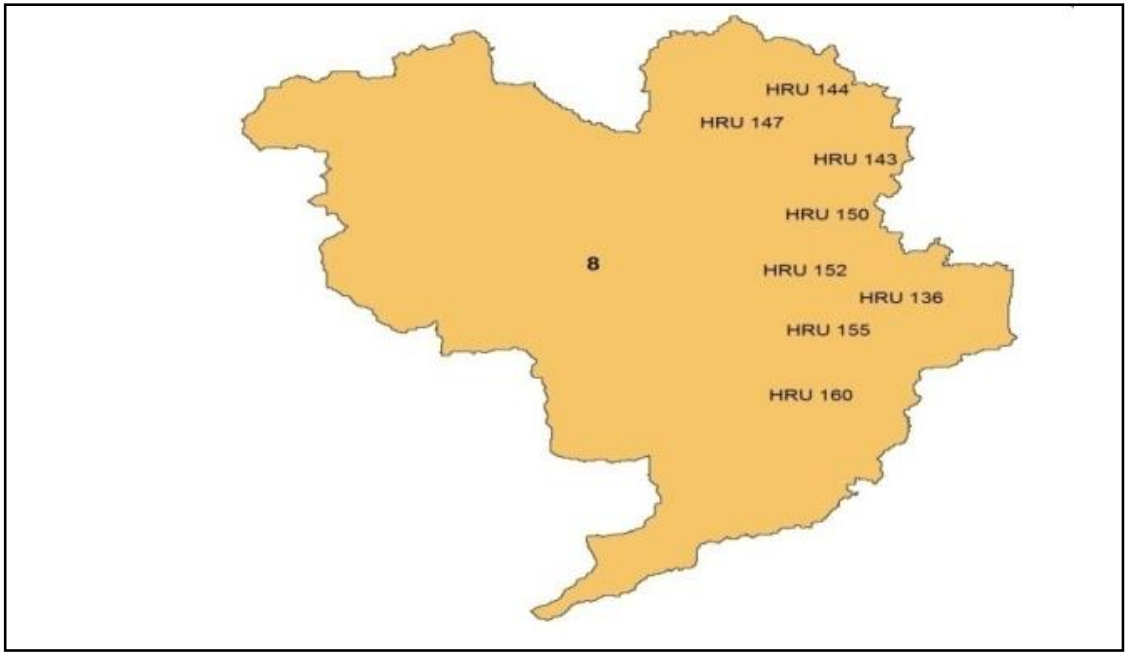

Figure 12: Showing the HRUs found in sub-basin 8 of Terengganu River catchment area

The figure 13 below is the cropped illustration of the position of HRUs found in sub-basin 18 in Terengganu River catchment area.

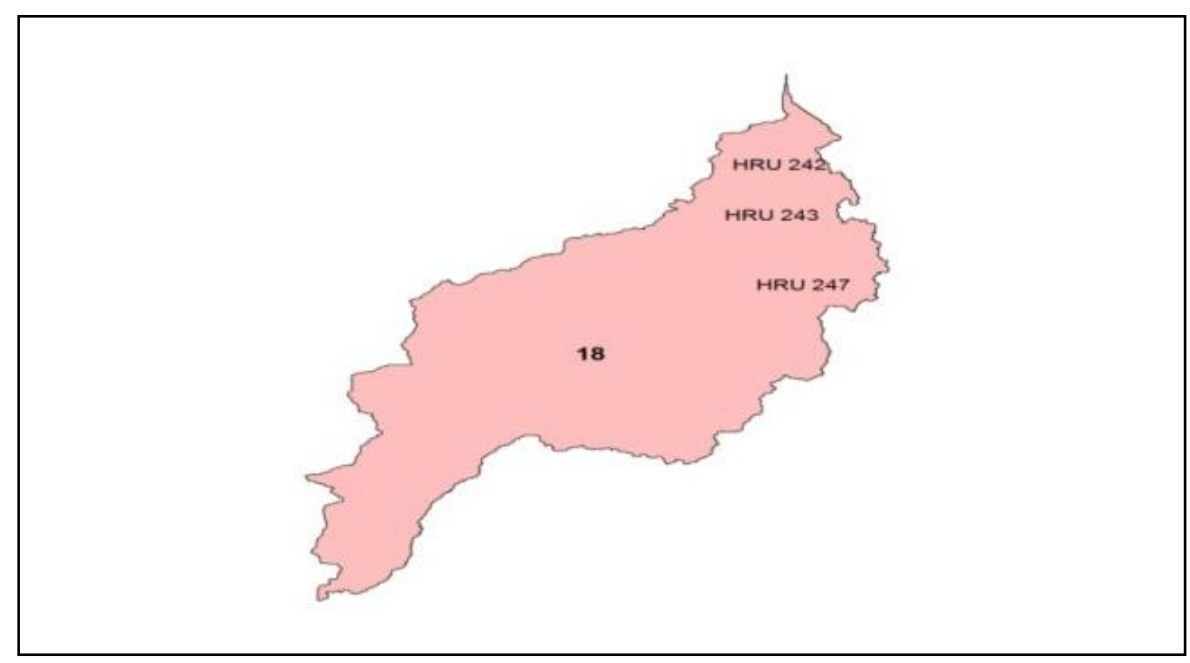

Figure 13: Showing the HRUs found in sub-basin 18 of Terengganu River catchment area

The further analysis of HRUs in Terengganu River catchment can be seen in figure 14 below showing different individual sub-basin HRU to show the density of each flood risk zones. For instance, the HRUs are divided base on their locations on each sub-basin and on slope level from 0-10 meter. Meaning that these are the vulnerable flood risk zones containing the HRUs from the sub-basin 3, 5, 7, 8, and 18 parameters. Table 2 is the summary of the individual flood risk impact. The same table 2 summarizes the total HRUs affected by flood (42) and the impacts total of 107,429. 
Table 2: The Summary of Impacts of HRUs in selected Sub-basin in Terengganu River Catchment Are

\begin{tabular}{|l|l|l|}
\hline $\begin{array}{l}\text { No. Sub-basins involved in } \\
\text { Flood }\end{array}$ & No. HRUs & Total flood Impacts \\
\hline 3 & 9 & 36,323 \\
\hline 5 & 8 & 2,394 \\
\hline 7 & 14 & 34,582 \\
\hline 8 & 8 & 19,780 \\
\hline 18 & 3 & 14,350 \\
\hline Total & 42 & 107,429 \\
\hline
\end{tabular}

Among the 5 sub-basins that are vulnerable to high flood risk in Terengganu River catchment area, the most affected HRUs with high flood risk impacts are found in sub-basin 3 with 36,323 ha, followed by subbasin 7 with 34,582 ha then sub-basin 8 with 19,750 ha, followed by the sub-basin 18 with 14,350 ha and the lowest impact are found in sub-basin 5 with 2,394 ha.

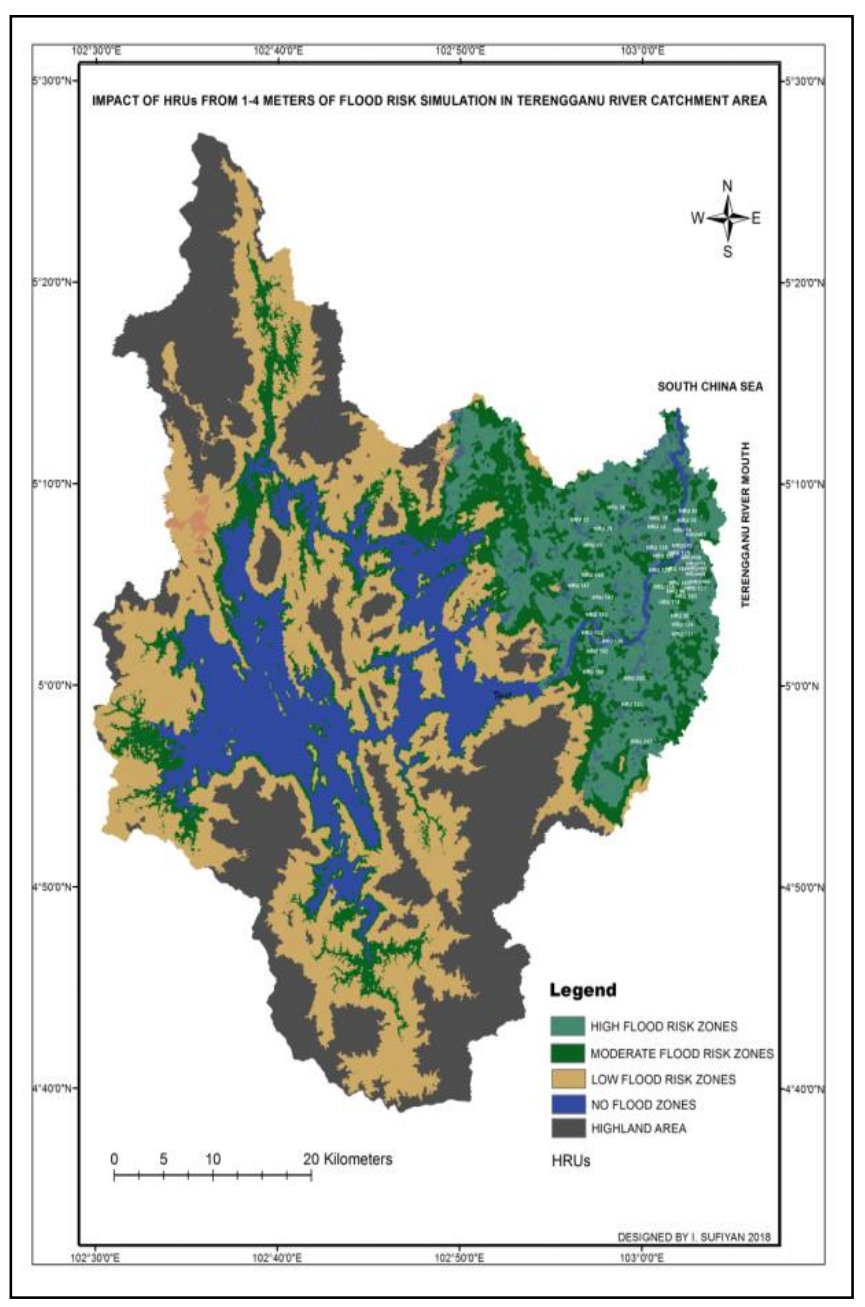

Figure 14: The HRUs vulnerable to high flood in the Terengganu River catchment area

The HRU of Kuala Brang is calculated based on individual HRU in sub-basin 5. For instance; the HRU 59 of Soil types (Kuala Brang) and Land cover types (Oil Palm) as in Table 4 for $1 \mathrm{~m}$ at flood level at 0-10 slope class was found by adding area [ha] of soil (Kuala Brang 152.8 [ha]) with Land cover (Oil Palm 152.8 [ha]) multiplied by the index number (4) of both Soil and Land cover. The impact result is 307 [ha] as shown in Table 5. Table 5 below presents the results of the impacts of the subsequent HRUs in the sub-basin 5 with $1 \mathrm{~m}$ flood level in Terengganu River catchment area. Table 3 shows the combined index of local soils and land cover found in Terengganu River catchment.

Table 3: Soil and land cover indexing of Terengganu River Catchment Area

\begin{tabular}{|l|l|l|l|l|l|}
\hline Soil Types & Index & $\begin{array}{c}\text { Land cover } \\
\text { Type }\end{array}$ & Index & Land cover & Index \\
\hline Steepland & 1 & $\begin{array}{l}\text { Forest } \\
\text { Evergreen }\end{array}$ & 2 & Orchard & 2 \\
\hline Kuala Brang & 4 & Water & 1 & Grassland & 1 \\
\hline Marang & 5 & Rubber Tree & 3 & & \\
\hline Telemong & 5 & Oil Palm & 4 & & \\
\hline Tok Yong & 3 & $\begin{array}{l}\text { Residential High } \\
\text { Density }\end{array}$ & 5 & & \\
\hline Peat & 2 & Paddy & 1 & & \\
\hline Rudua & 1 & $\begin{array}{l}\text { Residential Low } \\
\text { Density }\end{array}$ & 5 & & \\
\hline & \multicolumn{5}{|c|}{ Source: (Zonensein et al 2008, Kazakis et al 2015) } \\
\hline
\end{tabular}

While Table 4 was the selected HRUs impact to flood risk level at 1 meter. Different sub-basins that are susceptible to flood were having different HRUs that can be multiplied by the existing index number.

Table 4: HRU Impacts on $1 \mathrm{~m}$ Flood level from Sub-basin 5 in Terengganu River Catchment Area

\begin{tabular}{|l|l|l|l|l|l|l|}
\hline HRU & Soil & $\begin{array}{l}\text { Area } \\
{[\text { ha }]}\end{array}$ & Index & Land Cover & $\begin{array}{l}\text { Area } \\
{[\text { ha }]}\end{array}$ & Index \\
\hline 59 & $\begin{array}{l}\text { Kuala } \\
\text { Brang }\end{array}$ & 38.2 & 4 & Oil Palm & 38.2 & 4 \\
\hline 63 & $\begin{array}{l}\text { Telemong } \\
\text { nuala } \\
\text { Brang }\end{array}$ & 81.2 & 5 & Oil Palm & 81.2 & 4 \\
\hline 66 & $\begin{array}{l}\text { Telemong } \\
\text { Kual }\end{array}$ & 28.3 & 5 & Rubber Tree & 28.3 & 3 \\
\hline 72 & $\begin{array}{l}\text { Kuala } \\
\text { Brang }\end{array}$ & 22.8 & 4 & $\begin{array}{l}\text { Residential } \\
\text { High Density }\end{array}$ & 22.8 & 5 \\
\hline 75 & $\begin{array}{l}\text { Telemong } \\
\text { Kubber Tree }\end{array}$ & 9.9 & 3 \\
\hline 76 & $\begin{array}{l}\text { Kuala } \\
\text { Brang }\end{array}$ & 14.6 & 4 & $\begin{array}{l}\text { Residential } \\
\text { High Density }\end{array}$ & 54.2 & 5 \\
\hline 83 & $\begin{array}{l}\text { Telemong } \\
\text { Evergreen }\end{array}$ & 21 & 5 & $\begin{array}{l}\text { Forest } \\
\text { Evergreen }\end{array}$ & 21 & 2 \\
\hline
\end{tabular}

Table 5 below shows the HRU with the highest impact that is (HRU 63) with 810 in sub-basins 5. While the lowest impact of HRU in the same subbasin is found in the HRU 66 which has the total impacts of 69 refer to Table 5. 
Table 5: individual HRUs Impact of Soil and Land cover types for 1 meter Flood level of Terengganu River Catchment Area

\begin{tabular}{|l|l|l|l|l|l|l|l|}
\hline \multirow{2}{*}{ HRU } & \multicolumn{3}{|l|}{ Soil Types } & \multicolumn{5}{l|}{ Land Cover Types } & $\begin{array}{l}\text { Impact } \\
\text { of } \\
\text { Kuala } \\
\text { Brang }\end{array}$ & Telemong & $\begin{array}{l}\text { Oil } \\
\text { Palm }\end{array}$ & Rubber & URHD & $\begin{array}{l}\text { Forest } \\
\text { E }\end{array}$ & \begin{tabular}{l} 
Flod \\
\hline 59
\end{tabular} & 152.8 & & 152.8 & & & & 307 \\
\hline 63 & & 405 & 405 & & & & 810 \\
\hline 66 & 39.6 & & & 29.7 & & & 69 \\
\hline 69 & & 141.5 & & 84.9 & & & 226 \\
\hline 72 & 91.2 & & & & 114 & & 205 \\
\hline 75 & & 271 & & & 271 & & 542 \\
\hline 76 & 58.4 & & & & & 29.2 & 88 \\
\hline 83 & & 105 & & & & 42 & 147 \\
\hline Total & & & & & & & 2,394 \\
\hline
\end{tabular}

Figure 15 below is the spatial data that depicts the flooded zones at $1 \mathrm{~m}$. It was presented in form of the model to show the 3D flood simulation based on the Digital Elevation Model (DEM) of Terengganu River catchment area. This model output is essential for flood mitigation, planning and risk zoning to save lives and properties within the physical and socio-economic environment.

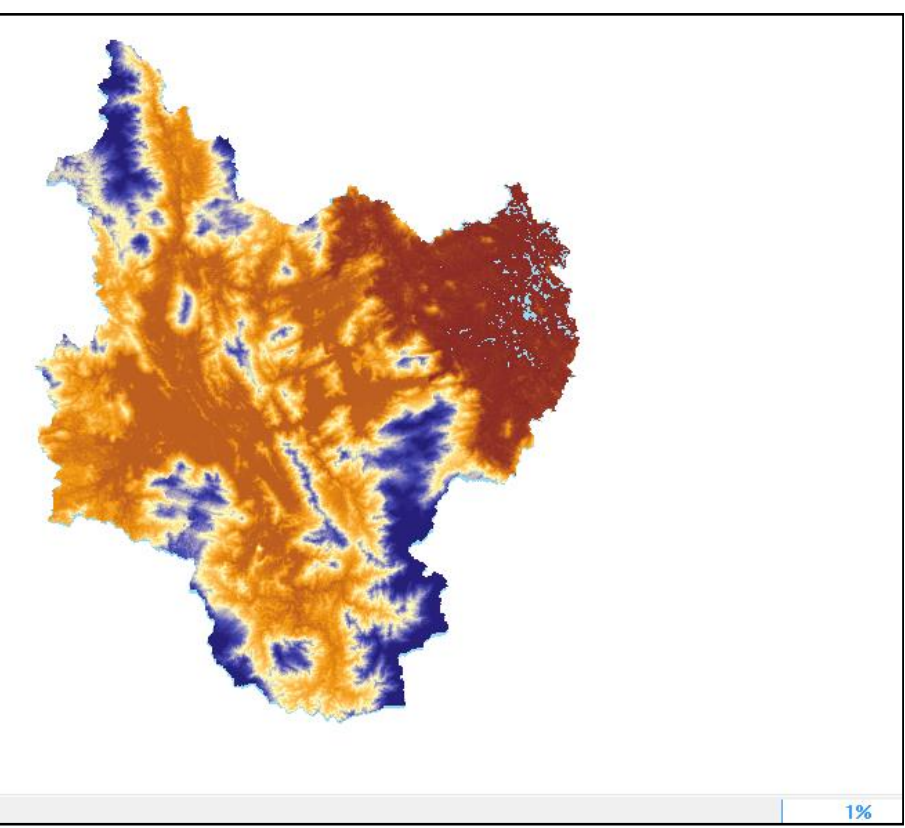

Figure 15: 3D Flood Risk Simulation Model

\section{CONCLUSION}

However, out of the total area of Terengganu River catchment area of (286, $507 \mathrm{ha}$ ) from the SWAT output refer to Table 4.1, (107, $429 \mathrm{ha})$ of the area are expected to have affected by the flood risk impacts. The remaining 179 , 078 ha of the Terengganu River catchment area is located at flood free zones.

The flood risk simulations overlaid with the major HRUs that are vulnerable to flood are presented in figure 5.51 below. Out of 305 HRUs, about 42 HRUs falls within the range of 0-10 meter of slope and are located at very high flood risk zones in Terengganu River catchment area.

The study of individual sub-basins in the watershed of Terengganu is important so much so that the stream flow within each sub-basin will be calculated for future flood study. The flooded zones are located mostly on the flat land; people should avoid building on flatlands for easy mitigation actions.

The study of flood hazard event is very vital in monitoring and controlling the sustainability of the environment. Flood was proven to be a natural phenomenon just like tsunami, earthquake, and volcanic eruption. For the purpose of this study, the application of the Soil Water Assessment Tool (SWAT) had produced results necessary for analysis of Hydrologic Response Units (HRUs).

\section{REFERENCES}

[1] Hassan, A.J., Ab. Ghani, A., Abdullah, R. 2006. Development of flood risk map using GIS for Sg. Selangor Basin. Proceeding 6th International Conf. on ASIA GIS, 9-10 Mac, UTM, 1-11.

[2] Carrara, A., Guzzetti, F. 2013. Geographical information systems in assessing natural hazards. Springer Science \& Business Media, 5.

[3] Schumann, A.H., Funke, R., Schultz, G.A. 2000. Application of a geographic information system for conceptual rainfall-runoff modeling. Journal of Hydrology, 240(1), 45-61.

[4] Rahmati, O., Samani, A.N., Mahdavi, M., Pourghasemi, H.R., Zeinivand, H. 2015. Groundwater potential mapping at Kurdistan region of Iran using analytic hierarchy process and GIS. Arabian Journal of Geosciences, 8(9), 7059-7071.

[5] Zerger, A. 2002. Examining GIS decision utility for natural hazard risk modeling. Environmental Modelling \& Software, 17(3), 287-294.

[6] Liu, Y.B., Gebremeskel, S., De Smedt, F., Hoffmann, L., Pfister, L. 2003. A diffusive transport approach for flow routing in GIS-based flood modeling. Journal of Hydrology, 283(1), 91-106

[7] Leopold, L.B., Wolman, M.G., Miller, J.P. 2012. Fluvial processes in geomorphology. Courier Corporation.

[8] Cotter, A.S., Chaubey, I., Costello, T.A., Soerens, T.S., Nelson, M.A. 2003. Water quality model output uncertainty as affected by the spatial resolution of input data. JAWRA Journal of the American Water Resources Association, 39(4), 977-986.

[9] Chaplot, V. 2005. Impact of DEM mesh size and soil map scale on SWAT runoff, sediment, and NO 3-N loads predictions. Journal of Hydrology, $312(1), 207-222$.

[10] DeLiberty, T.L., Legates, D.R. 2003. Interannual and seasonal variability of modeled soil moisture in Oklahoma. International Journal of Climatology, 23(9), 1057-1086.

[11] Galván, L., Olías, M., de Villarán, R.F., Santos, J.M.D., Nieto, J.M. Sarmiento, A.M., Cánovas, C.R. 2009. Application of the SWAT model to an AMD-affected river (Meca River, SW Spain). Estimation of transported pollutant load. Journal of Hydrology, 377(3), 445-454.

[12] Onuşluel Gül, G., Rosbjerg, D. 2010. Modeling of hydrologic processes and potential response to climate change through the use of a multisite SWAT. Water and Environment Journal, 24(1), 21-31.

[13] Stehr, A., Debels, P., Romero, F., Alcayaga, H. 2008. Hydrological modeling with SWAT under conditions of limited data availability: evaluation of results from a Chilean case study. Hydrological Sciences Journal, 53(3), 588-601.

[14] Thampi, S.G., Raneesh, K.Y., Surya, T.V. 2010. Influence of scale on SWAT model calibration for streamflow in a river basin in the humid tropics. Water Resources Management, 24(15), 4567-4578.

[15] Baker, T.J., Miller, S.N. 2013. Using the Soil and Water Assessment Tool (SWAT) to assess land use impact on water resources in an East African watershed. Journal of Hydrology, 486, 100-111. 
[16] Narasimhan, B., Srinivasan, R., Arnold, J.G., Di Luzio, M. 2005. Estimation of long-term soil moisture using a distributed parameter hydrologic model and verification using remotely sensed data. Transactions of the ASAE, 48(3), 1101-1113.

[17] Betrie, G.D., Mohamed, Y.A., van Griensven, A., Srinivasan, R. 2011. Sediment management modeling in the Blue Nile Basin using the SWAT model. Hydrology and Earth System Sciences, 15(3), 807.

[18] Marghany, M., Ibrahim, Z., Van Genderen, J. 2002. Azimuth cut-off model for significant wave height investigation along coastal water of Kuala Terengganu, Malaysia. International Journal of Applied Earth Observation and Geoinformation, 4(2), 147-160.

[19] Strahler, A.H., Boschetti, L., Foody, G.M., Friedl, M.A., Hansen, M.C., Herold, M., Woodcock, C.E. 2006. Global land cover validation: Recommendations for evaluation and accuracy assessment of global land cover maps. European Communities, Luxembourg, 51(4).
[20] Kalcic, M.M., Chaubey, I., Frankenberger, J. 2015. Defining Soil and Water Assessment Tool (SWAT) hydrologic response units (HRUs) by field boundaries. International Journal of Agricultural and Biological Engineering, 8(3), 69-80.

[21] Arnold, J.G., Srinivasan, R., Muttiah, R.S., Williams, J.R. 1998. Large area hydrologic modeling and assessment part I: Model development1. Wiley Online Library.

\section{APPENDIX}

\section{Dataset from the ArcSWAT2012 (2017)}

\section{STREAM FLOW IN RESULT 2017}

The Average Terengganu watershed stream flow into reservoir during time step $(\mathrm{m} 3 / \mathrm{s} \mathrm{H} 2 \mathrm{O})$ is 1274 as in figure ...., and the maximum flow of the stream flow is $3018 \mathrm{~m} 3 / \mathrm{s}$ is in sub-basin 1 and the minimum is $125.9 \mathrm{~m} 3 / \mathrm{s}$ in sub-basin 25 .

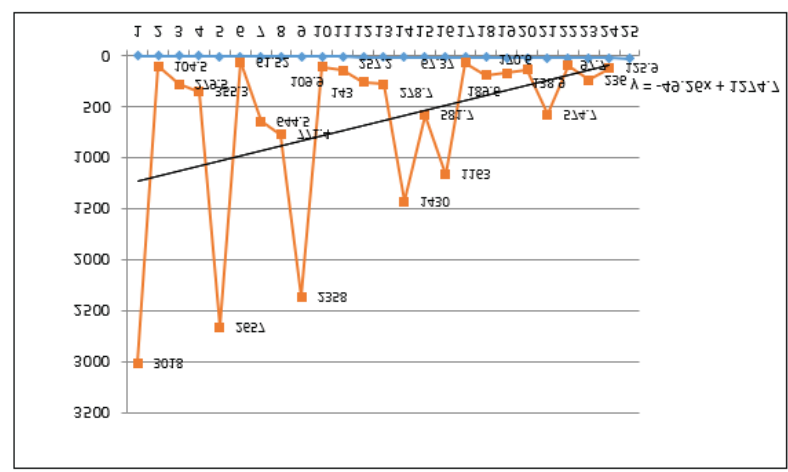

the Average stream flow out of reservoir during time step (m3/s H20)in Terengganu watershed was estimated to be 140 . The highest flow is $339.3 \mathrm{~m} 3 / \mathrm{s}$ of water while the lowest flow is $13.65 \mathrm{~m} 3 / \mathrm{s}$ refer to figure......

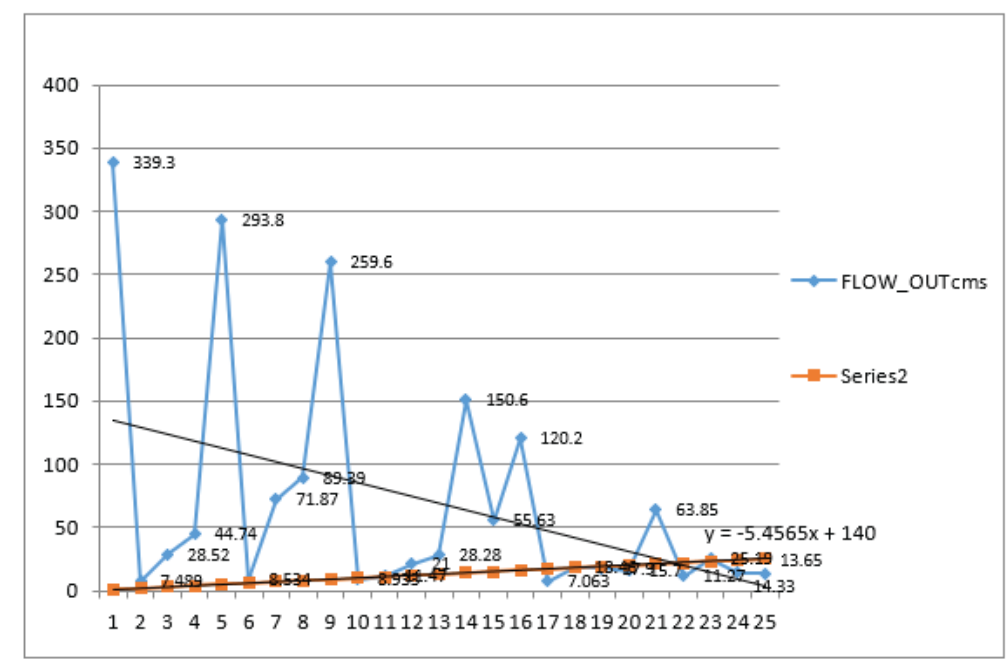

The rainfal pattern is averagely range between 2000 to $1900 \mathrm{~mm}$. This is typically showing the high intensity of rainfall which fall in the monsoon type of climate. The simulation result of the Terengganu watershed indicates highest rainfall with more than $2600 \mathrm{~mm}$ and the lowest is $850 \mathrm{~mm}$. The rainfall trend figure ...... has affluend effect of flood due to excessive heavy down pour of rain. 


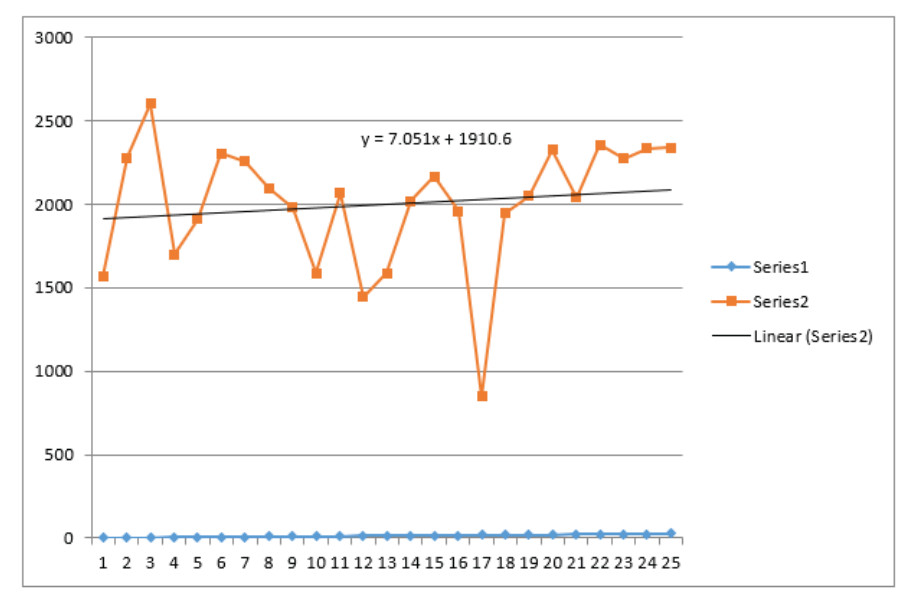

Figure ...... show the average evaporation of water in the Terengganu watershed. The highest evaporation is more in the sub-basin 5 with $0.164 \mathrm{~cm} / \mathrm{s}$, followed by sub-basin 9 with $0.108 \mathrm{~cm} / \mathrm{s}$ and sub-basin 7 with $0.092 \mathrm{~cm} / \mathrm{s}$. The lowest evaporation is in sub-basin 22 with $0.0003 \mathrm{~cm} / \mathrm{s}$.

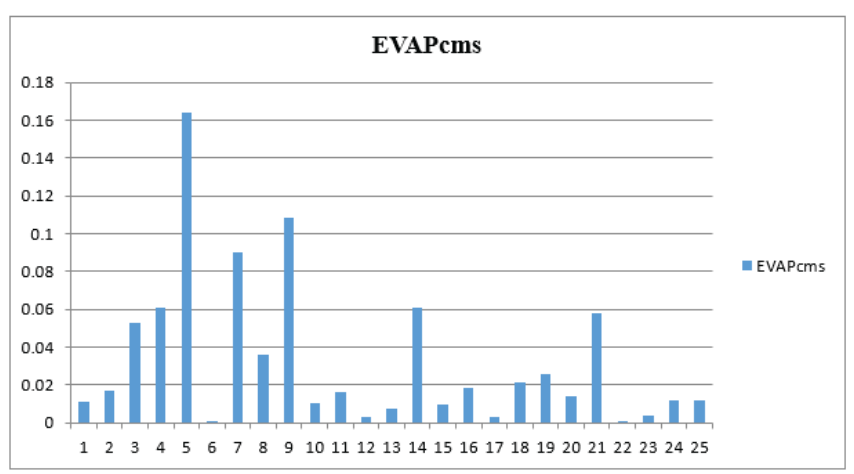

The figure ...... shows the total area occupied by each of the sub-basin within the catchment area of Terengganu. The biggest area of is in subbasin 1 with $3018 \mathrm{~km} 2$ and sub-basin 6 is smallest with $61.52 \mathrm{~km} 2$.

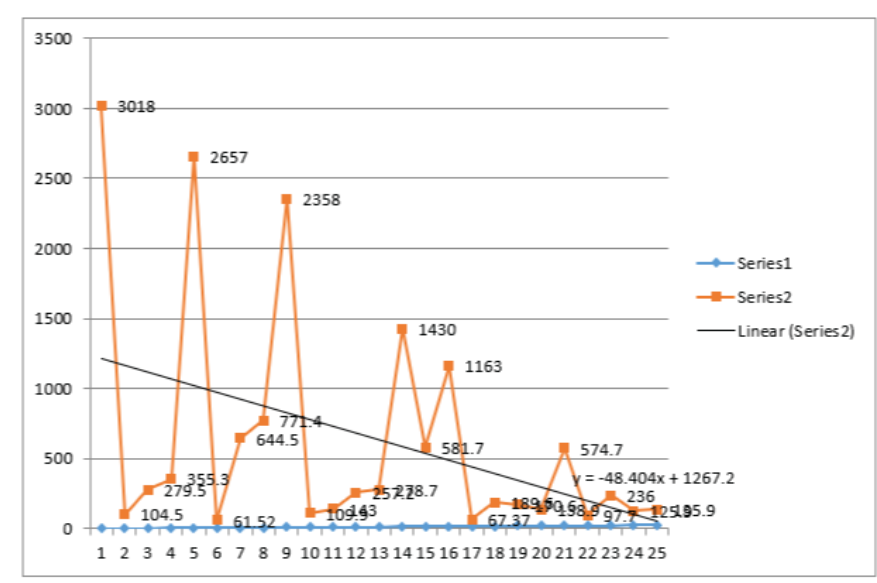

\section{STREAM FLOW -IN}

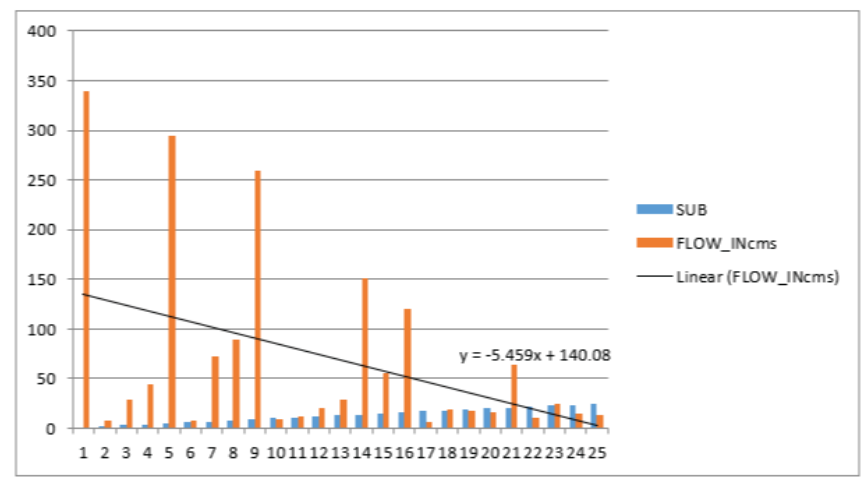

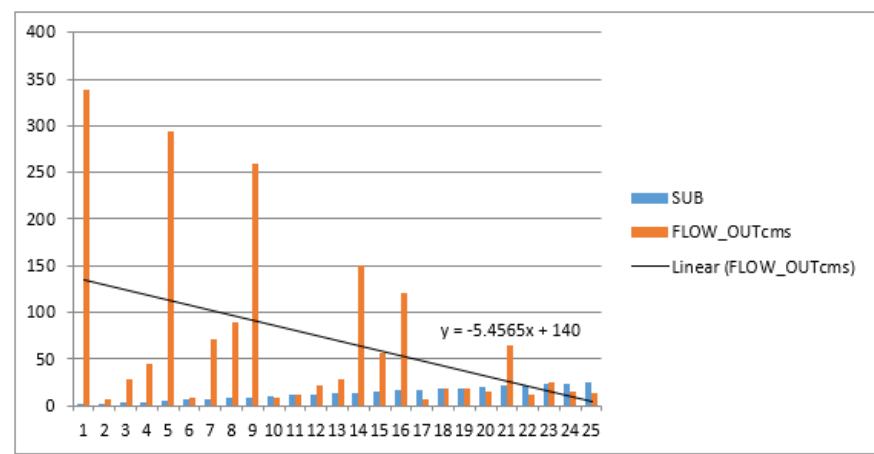

Sediment yeild in

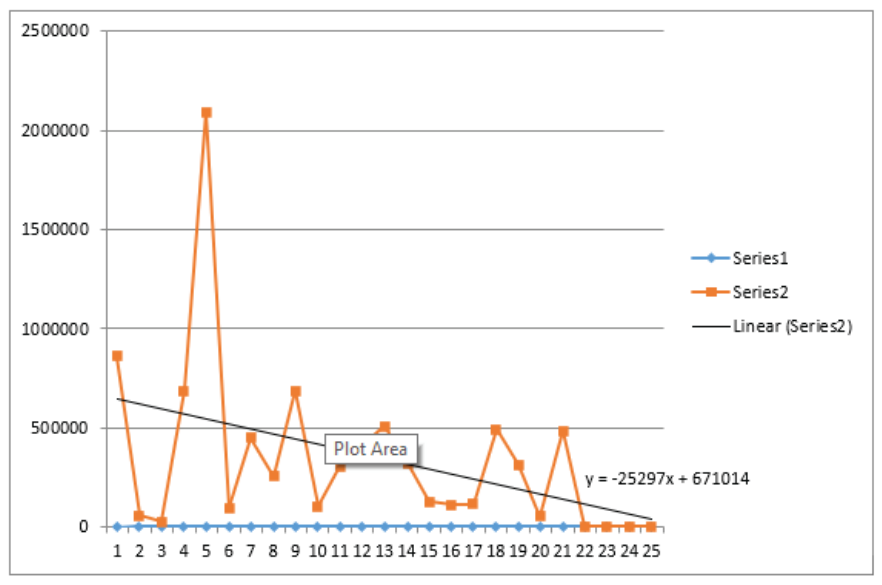

Sediment yield_out

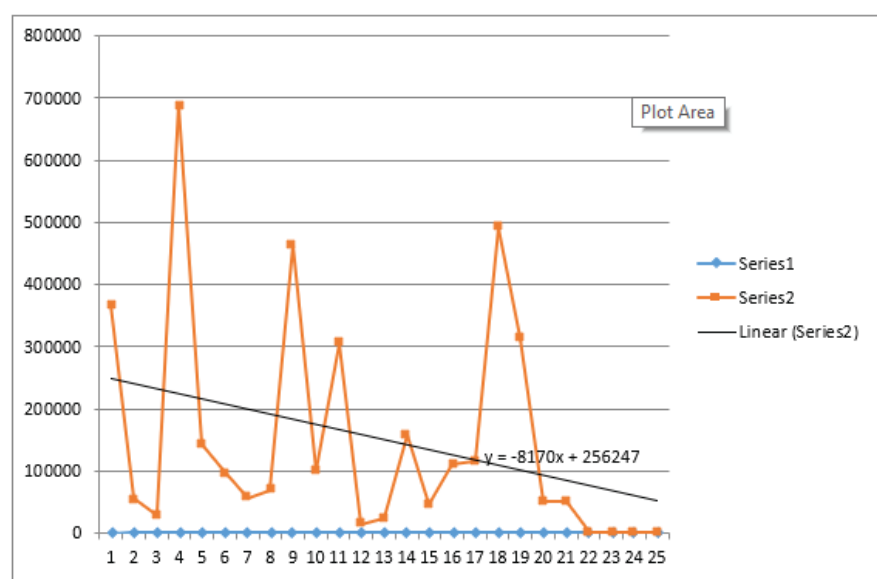

SEDIMENT CONCENTRATION

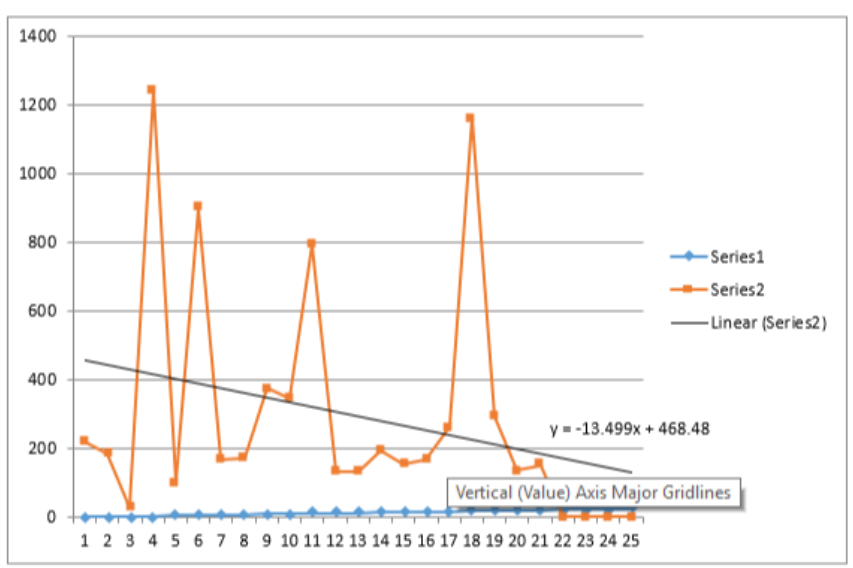

EVAPOTRASPIRATION 2017 


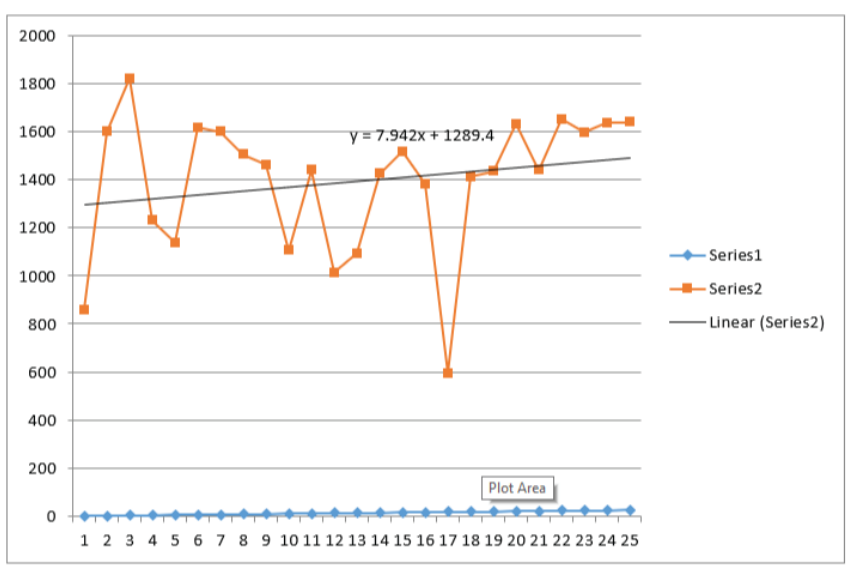

SOIL WATER CONTENT 2017 (SAME WITH 1973)

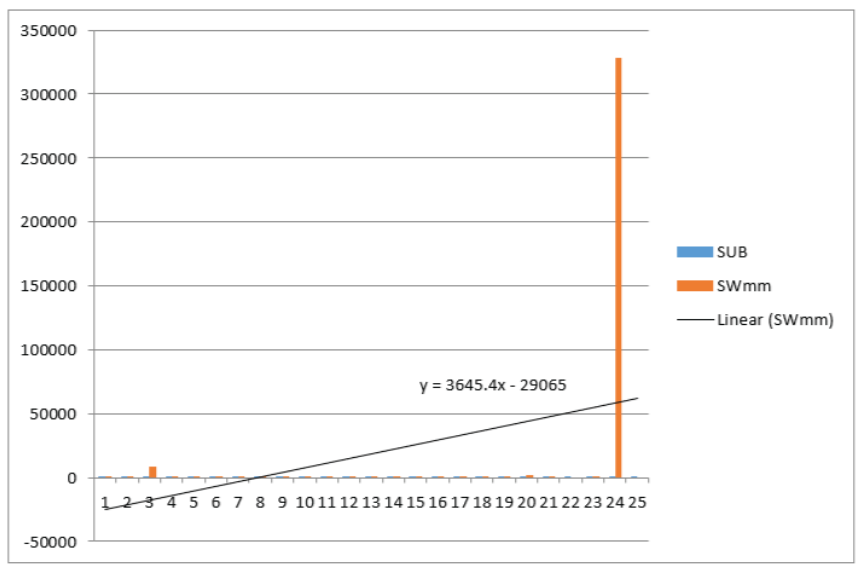

\section{PERCOLOATION}

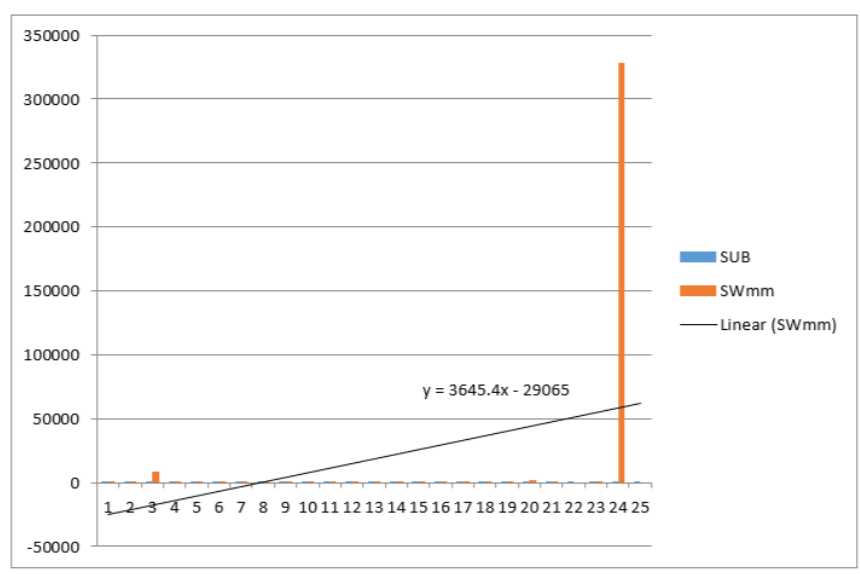

\section{SURFACE RUNOFF}

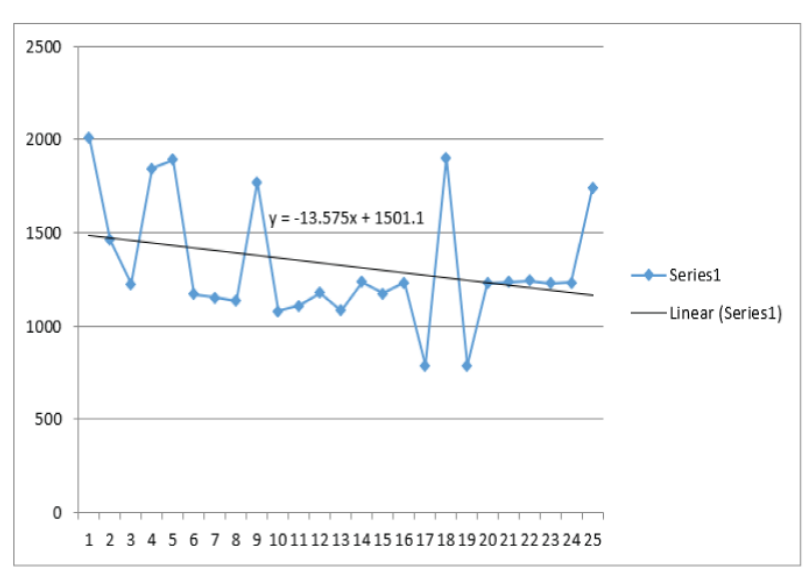

Groundwater contribution to streamflow (mm H2O)

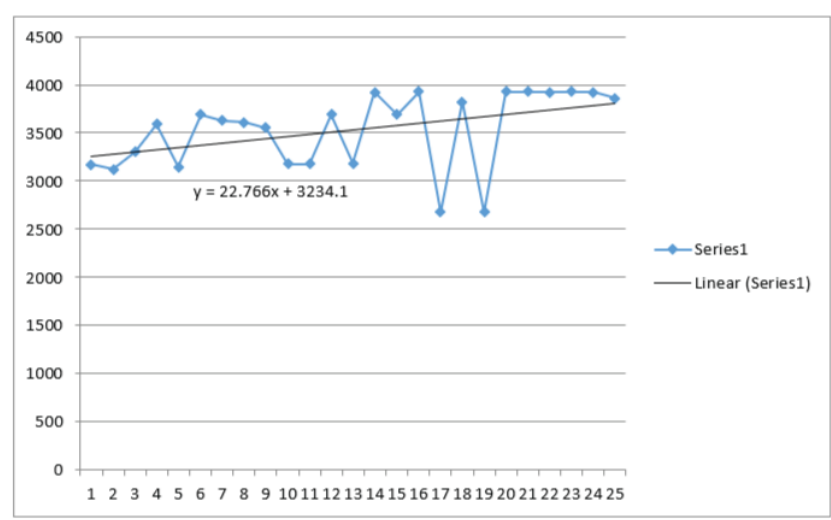

Water yield (mm H2O). Total amount of water leaving the HRU and entering main channel during the time step.

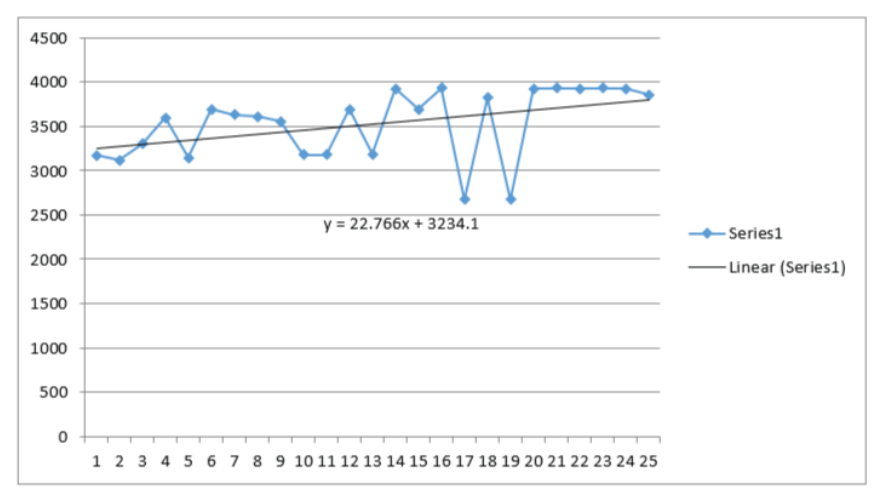

Sediment yield (metric tons/ha). Sediment from the HRU that is transported into the main channel during the time step.

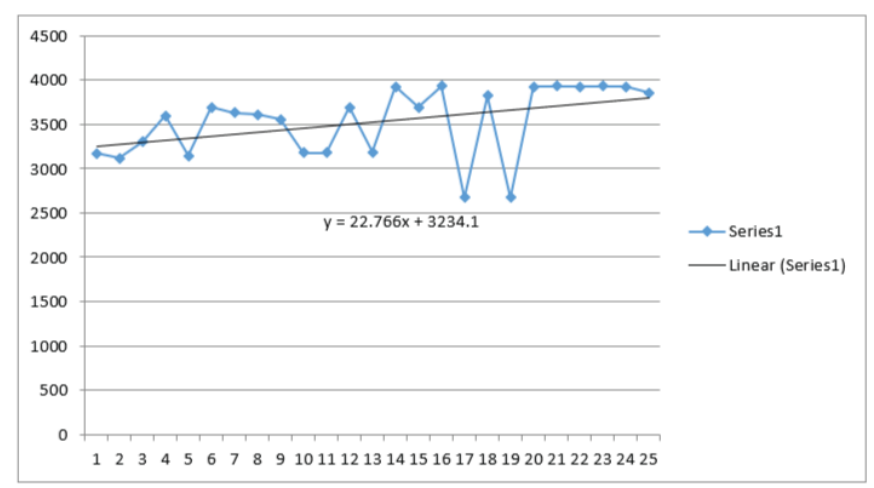

Average curve number for time period. The curve number adjusted for soil moisture content

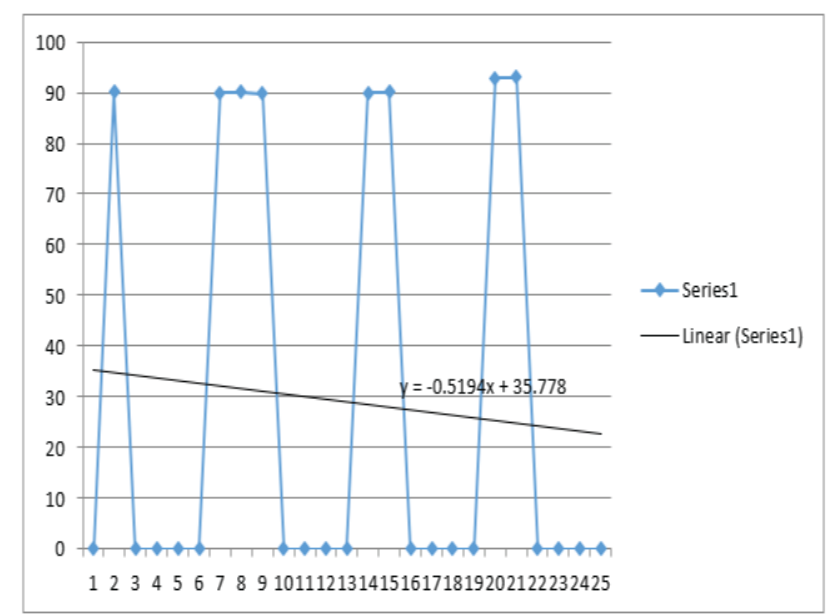

TEMP_AV 


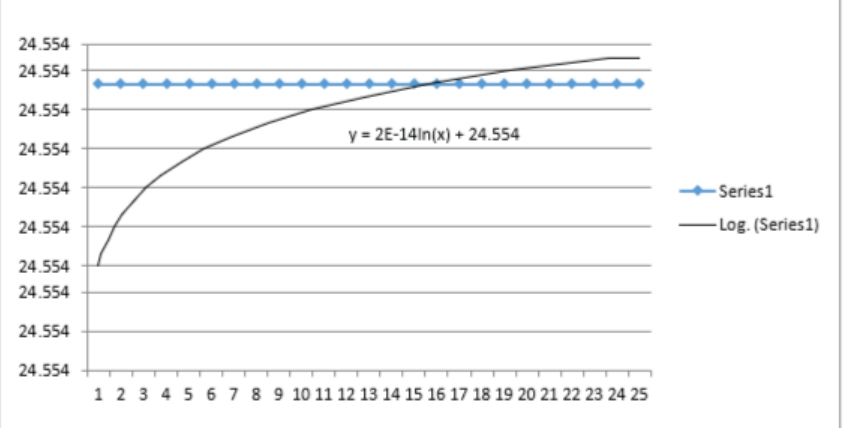

TEMP_MX

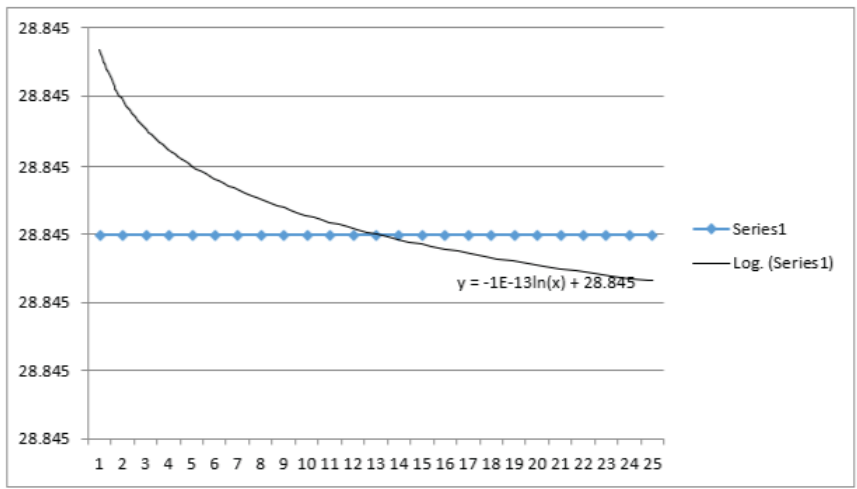

TEMP_MN

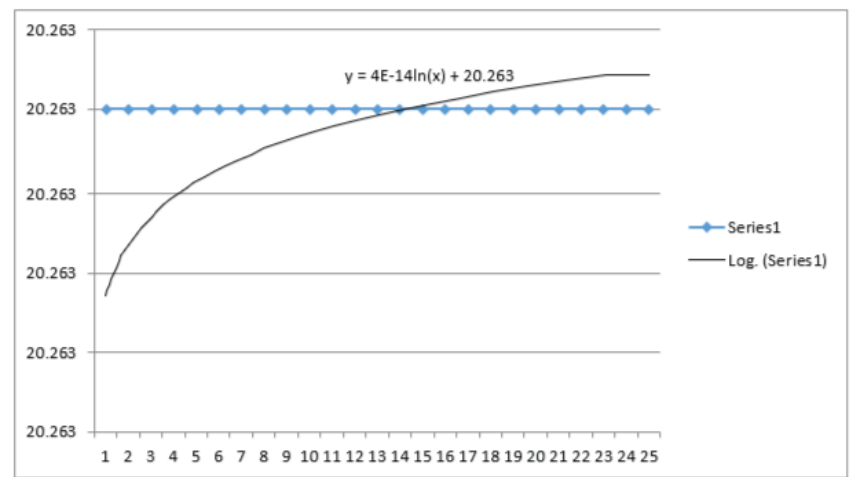

SOL_TMP

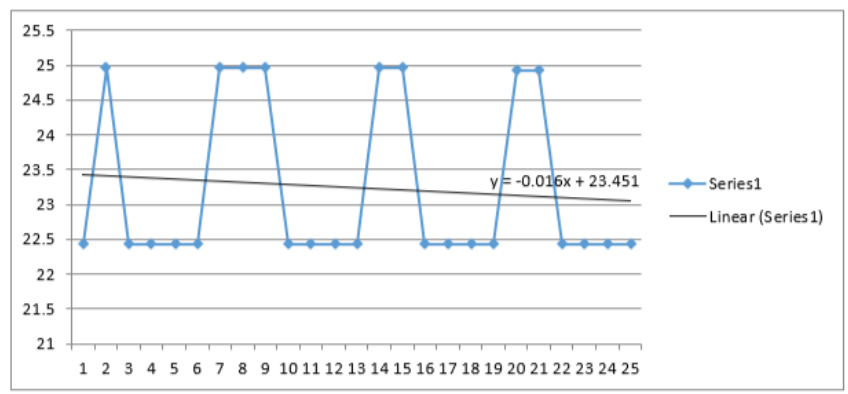

SOLARmj_m2

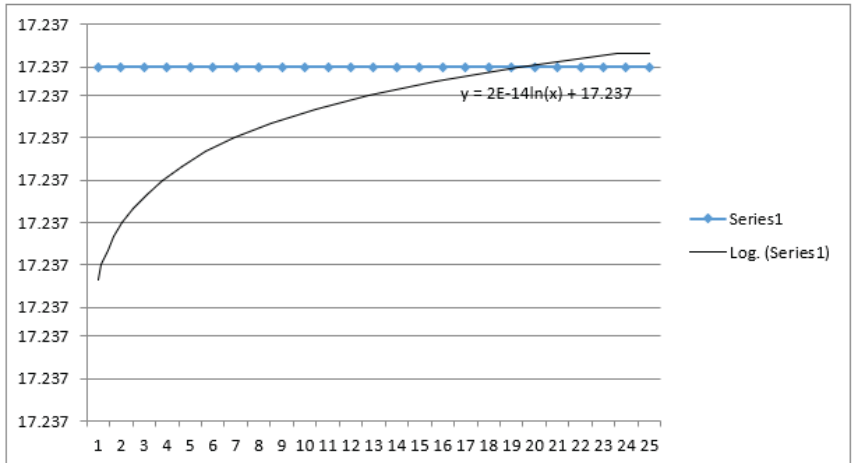

\section{SYLDt_ha}

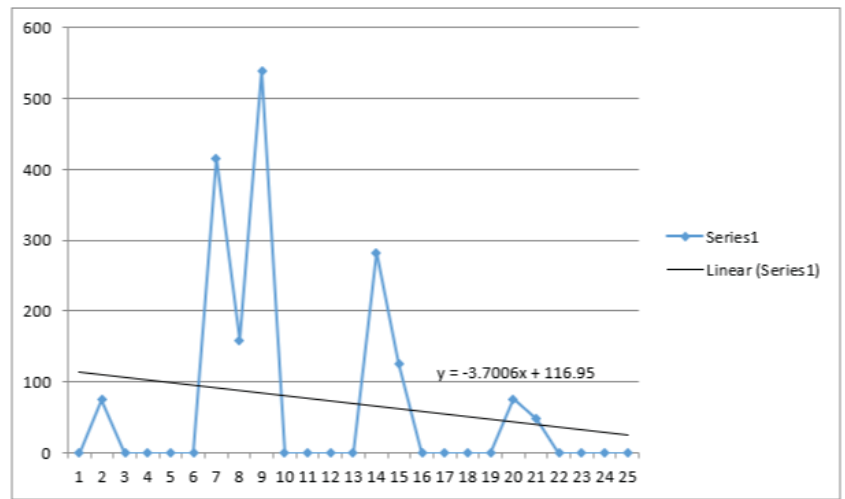

\section{USLEt_ha}

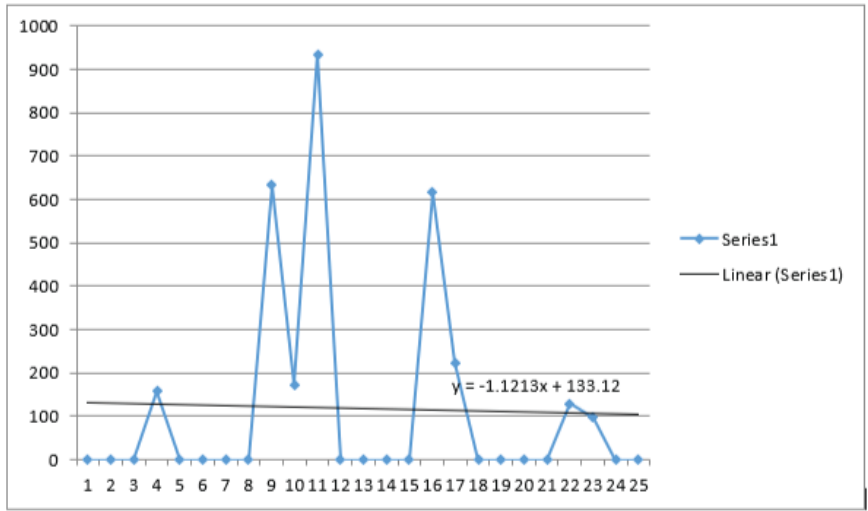

\section{WATB_SOL}

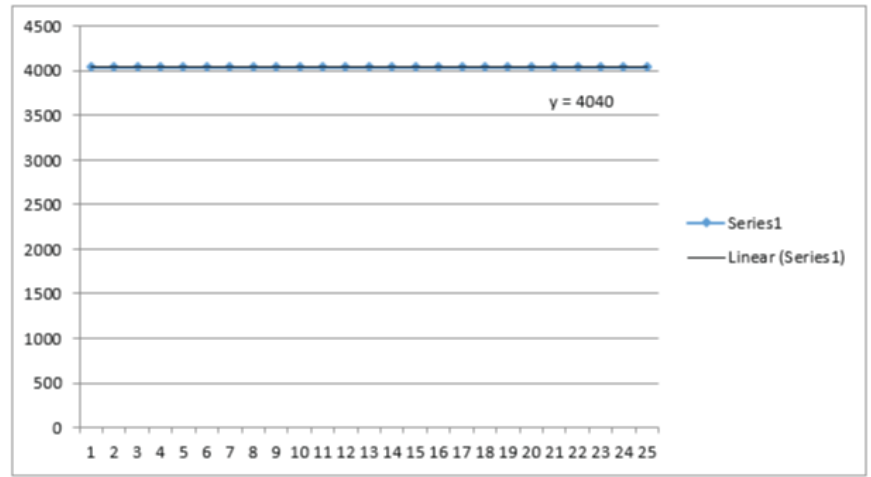

AREA OF SUBBASIN IN 1973 


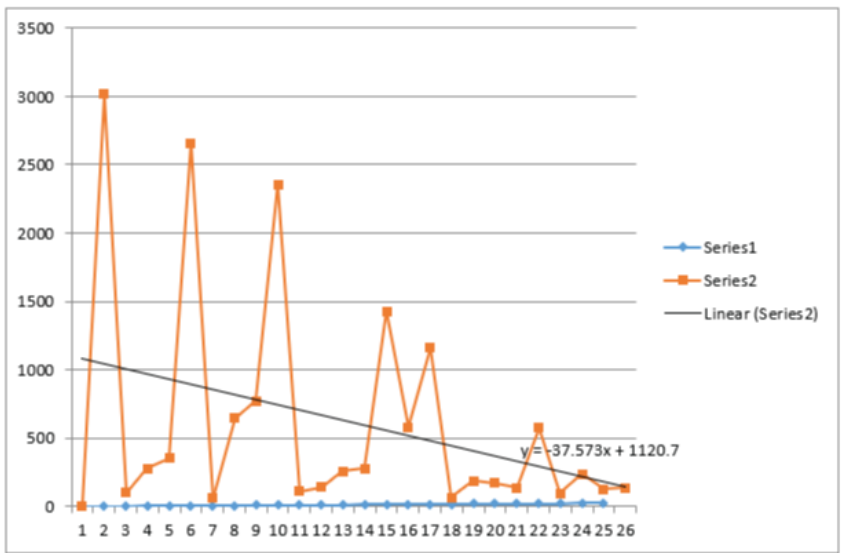

SREAM_IN

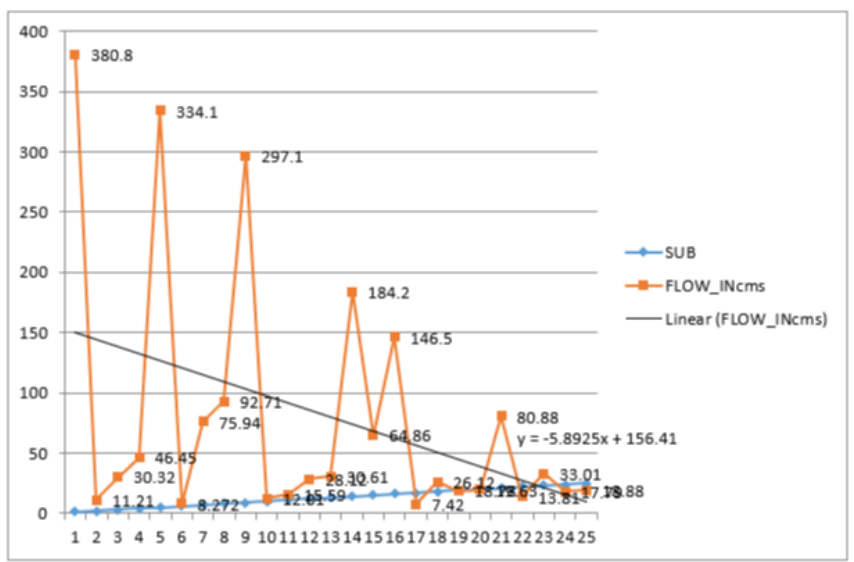

STREAM_OUT

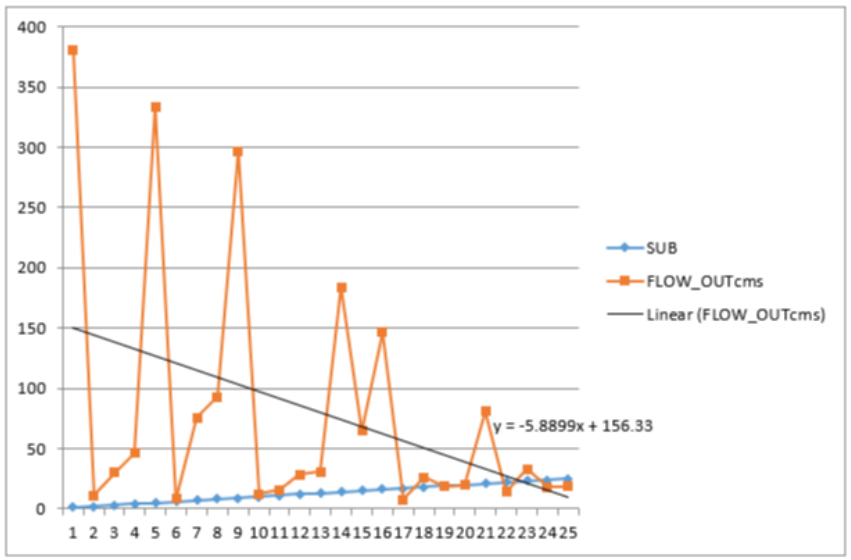

SEDIMENT_IN

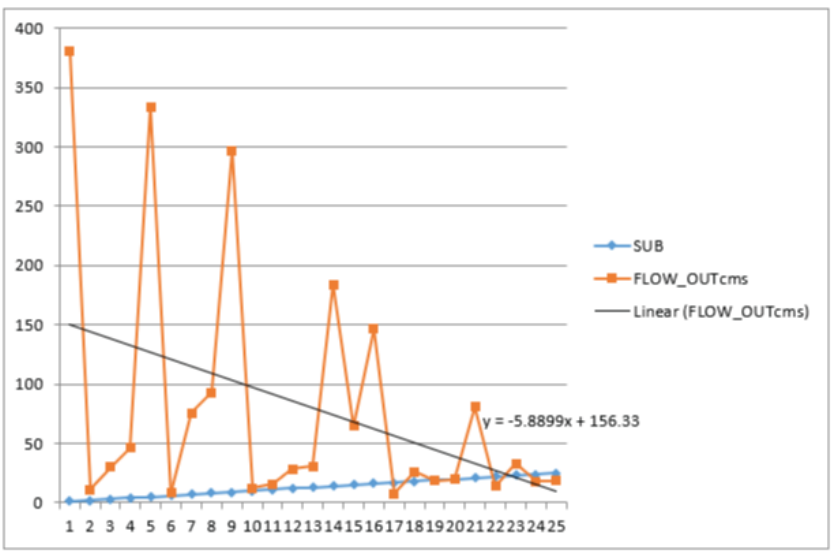

SEDIMENY_OUT

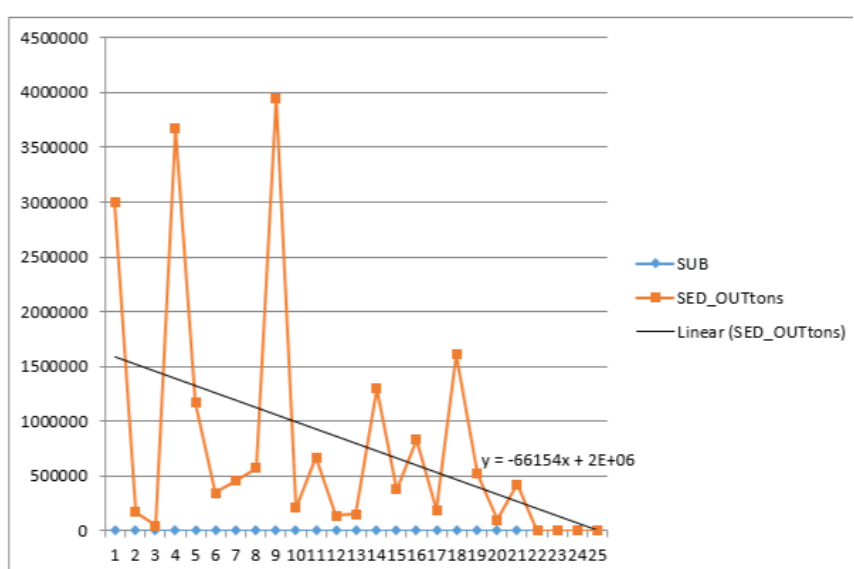

SEDIMENT CONCENTRATION

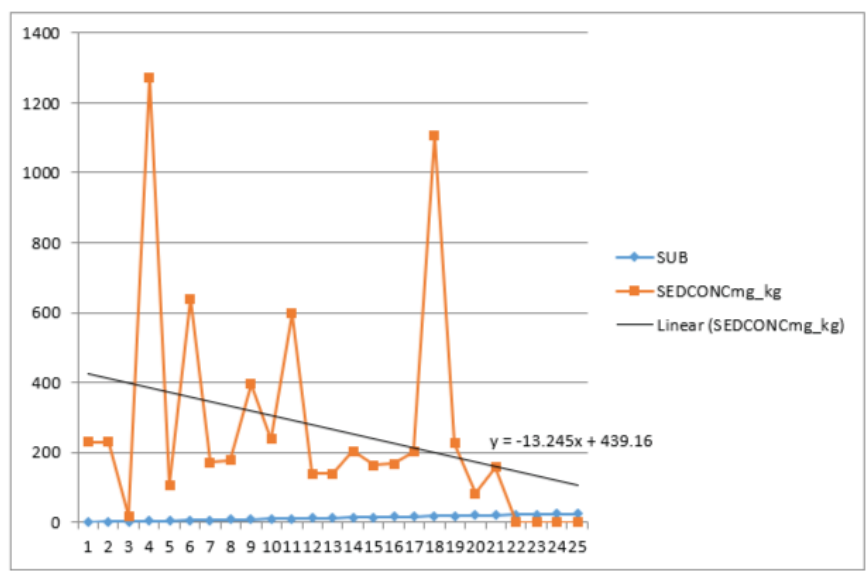

Rainfall 1973

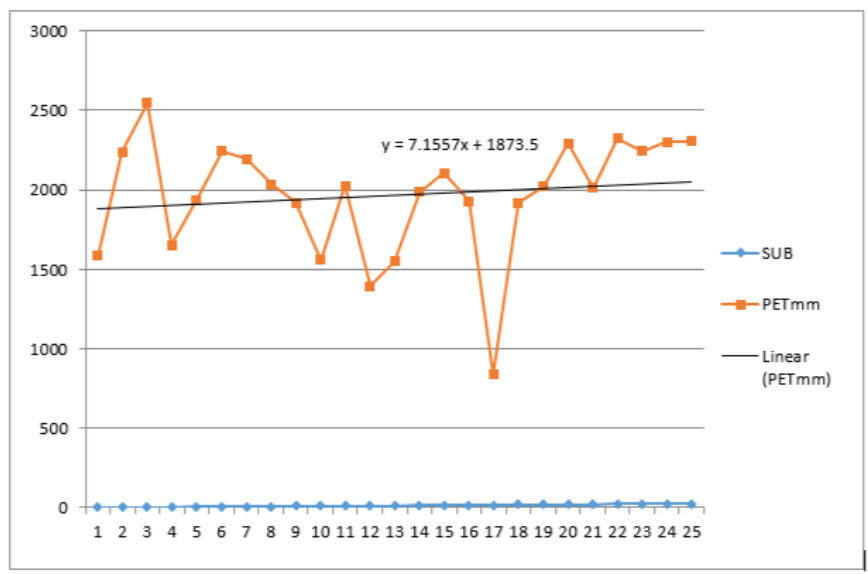

EVAPOTRANSPIRATION

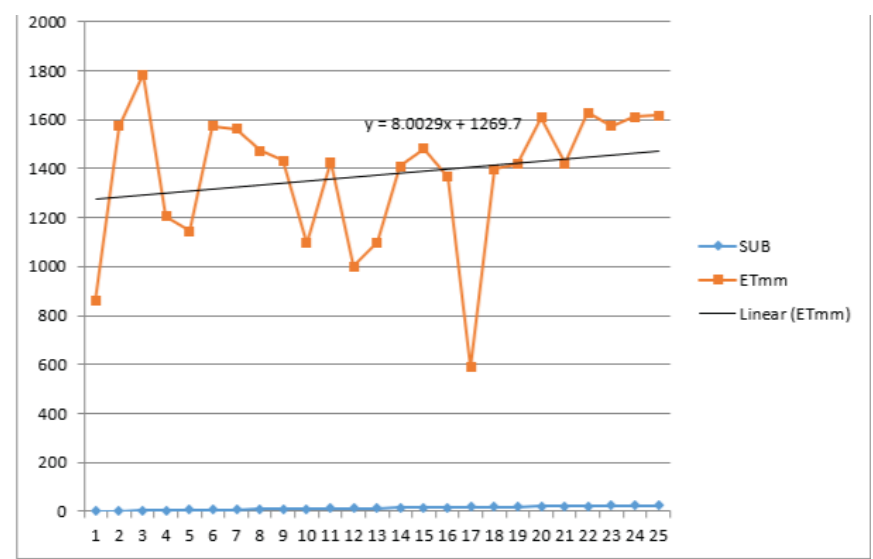




\section{SOIL WATER CONTENT}

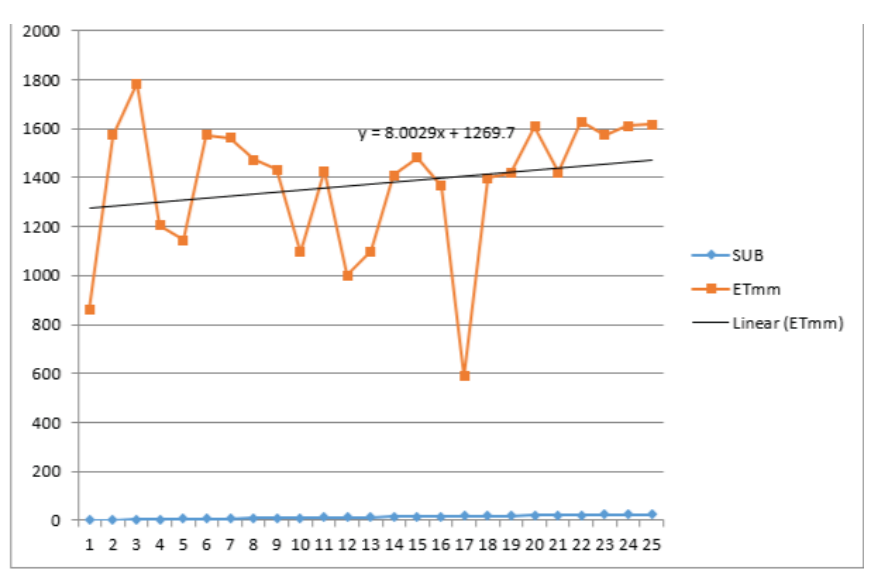

PERCOLATION

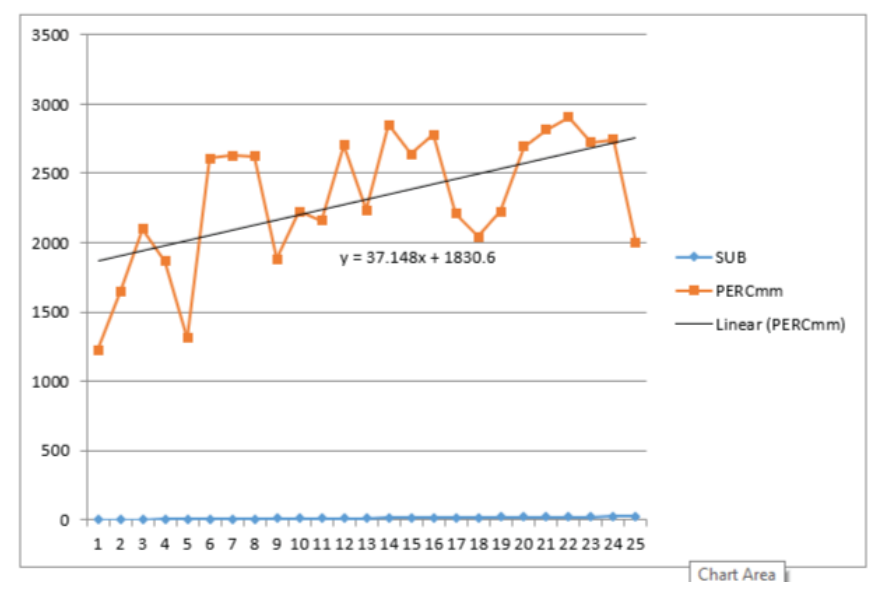

SURFACE RUNOFF

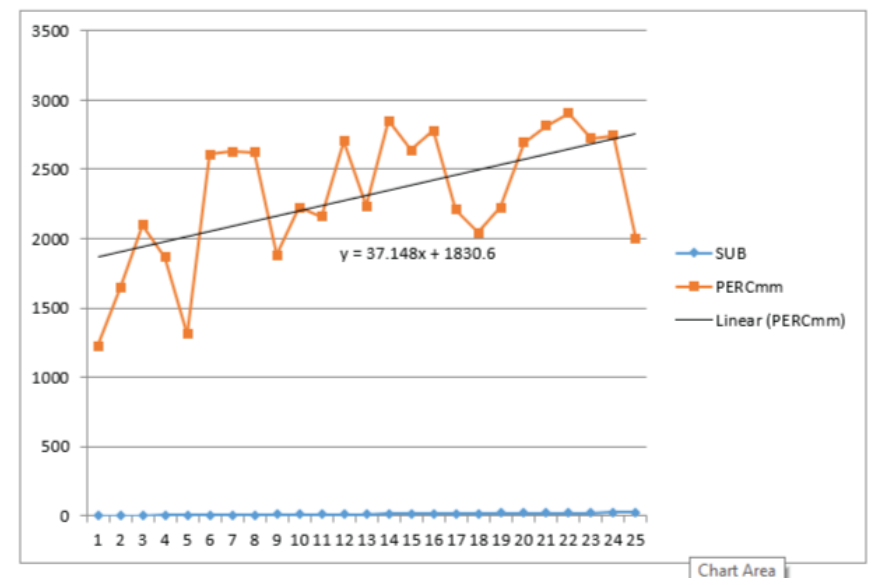

Groundwater contribution to streamflow (mm H2O)

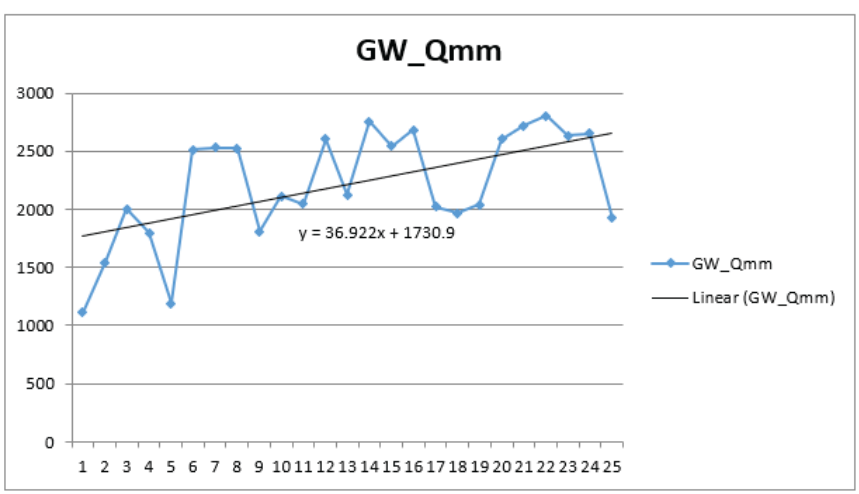

Water yield (mm H2O). Total amount of water leaving the HRU and entering main channel during the time step.

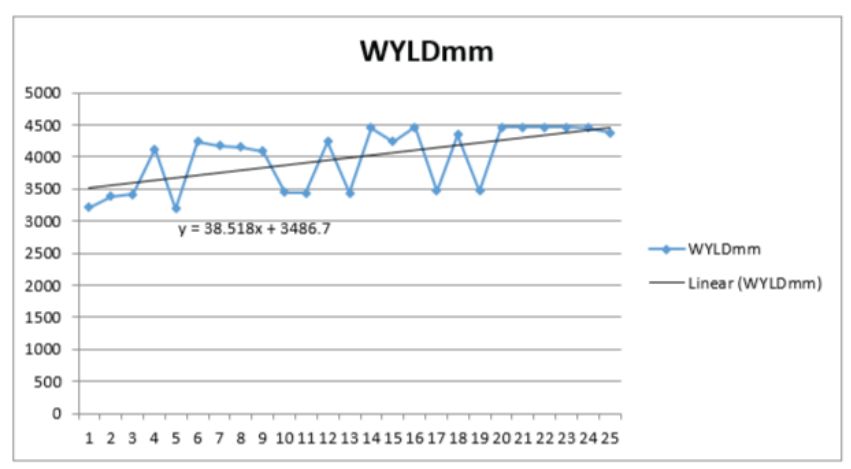

Sediment yield (metric tons/ha). Sediment from the HRU that is transported into the main channel during the time step.

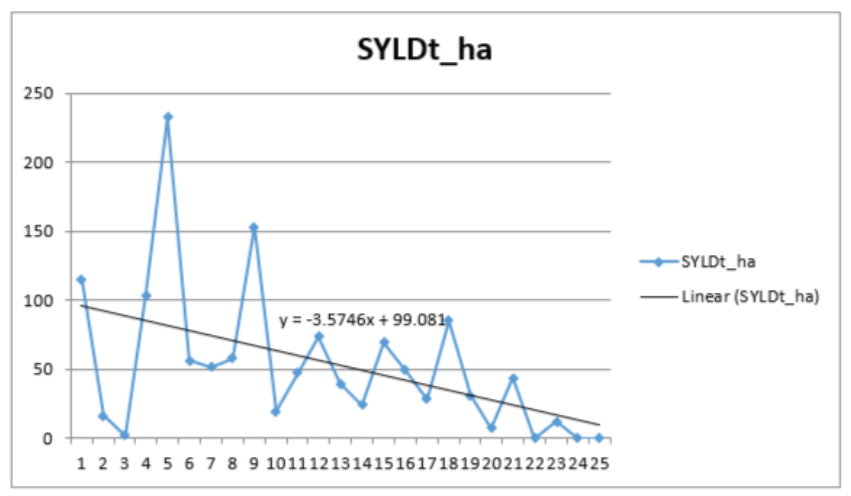

Average curve number for time period. The curve number adjusted for soil moisture content.
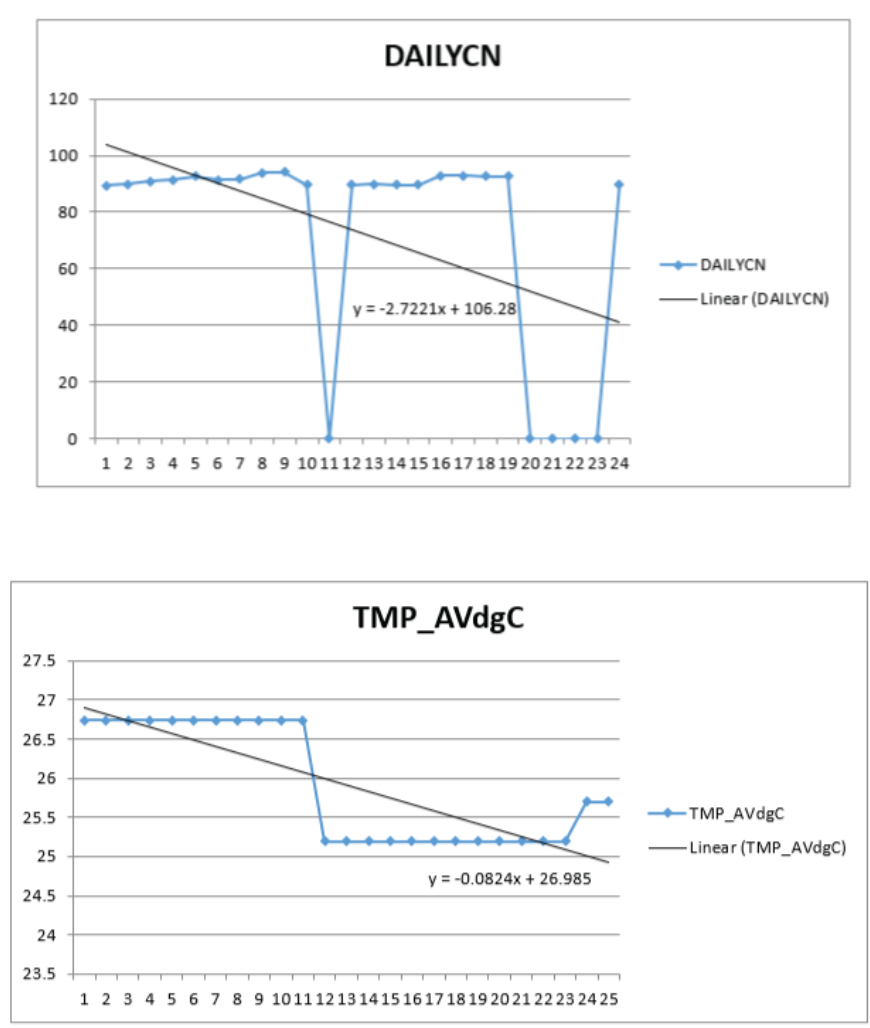

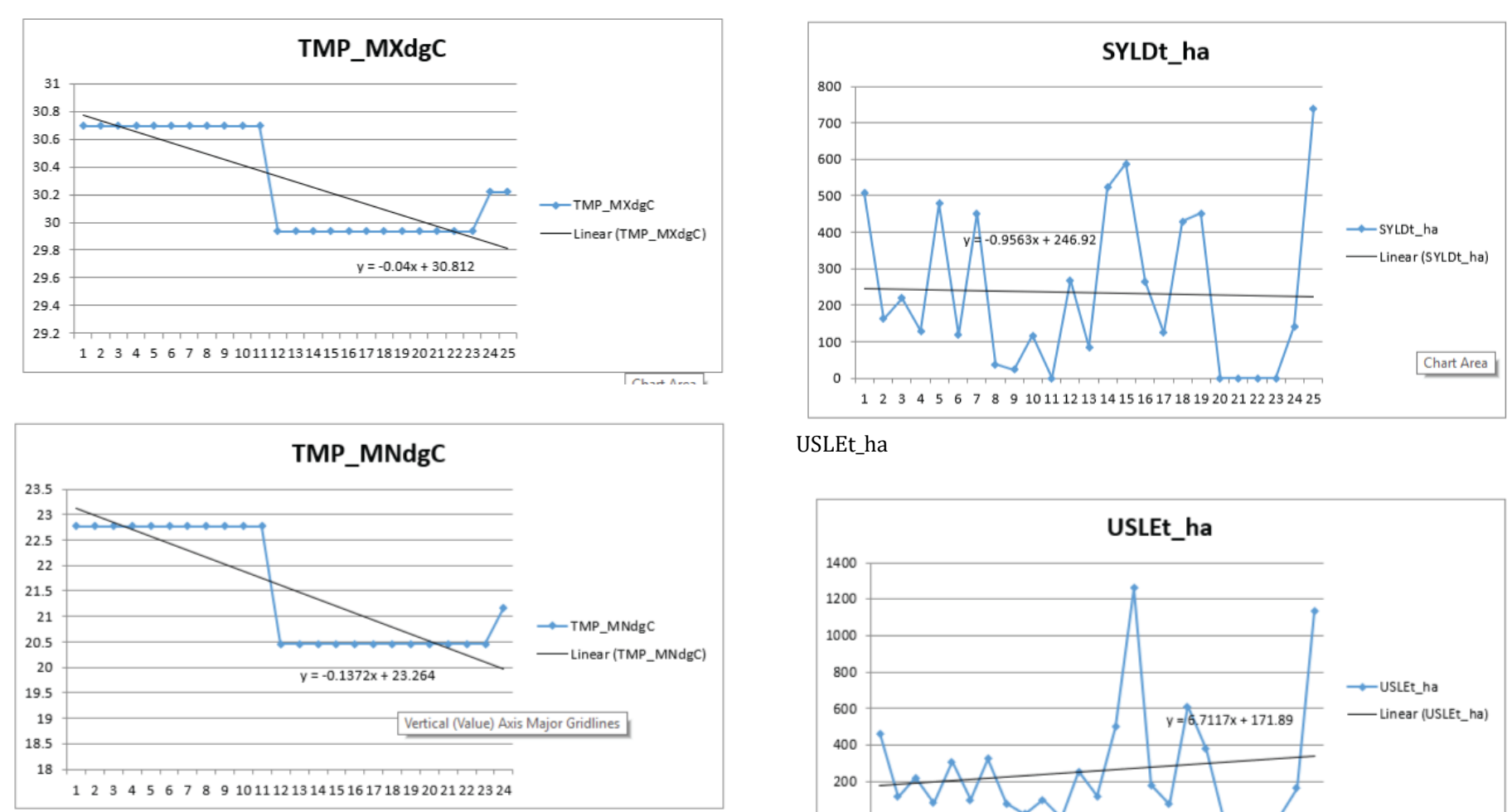

USLEt_ha

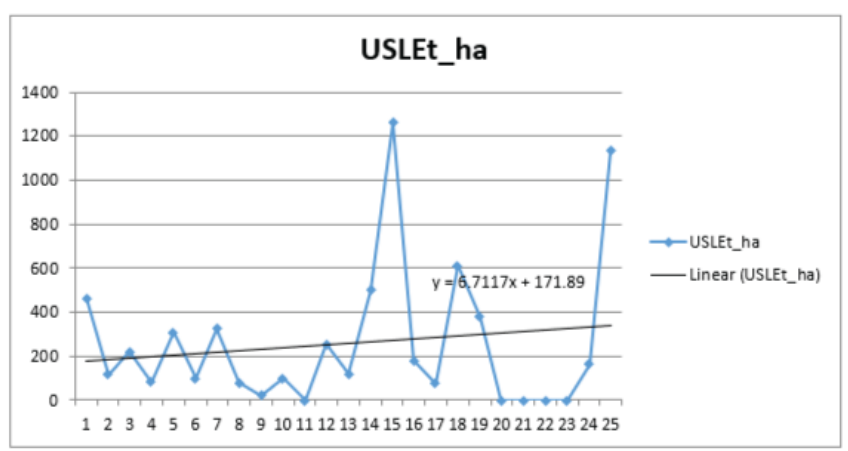

WATB_SOL
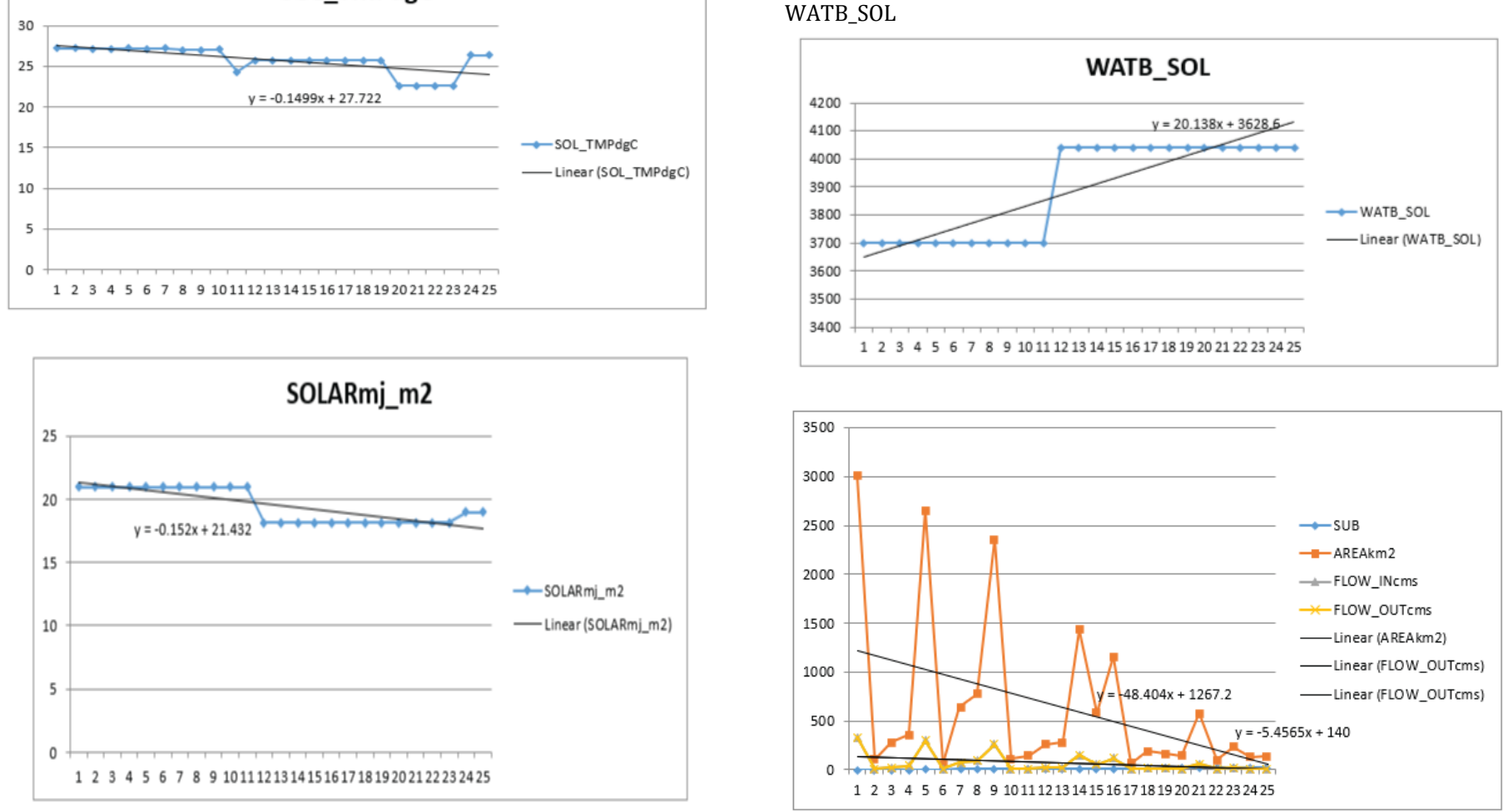